NEW EVIDENCE ON PENSIONS,

SOCIAL SECURITY, AND THE TIMING

OF RETIREMENT

Andrew A. Samwick

Working Paper 6534 
NBER WORKING PAPER SERIES

\title{
NEW EVIDENCE ON PENSIONS, SOCIAL SECURITY, AND THE TIMING OF RETIREMENT
}

Andrew A. Samwick

\author{
Working Paper 6534 \\ http://www.nber.org/papers/w6534 \\ NATIONAL BUREAU OF ECONOMIC RESEARCH \\ 1050 Massachusetts Avenue \\ Cambridge, MA 02138 \\ April 1998
}

A previous version of this paper circulated as "The Joint Effect of Social Security and Pensions on the Timing of Retirement: Some New Evidence." I would like to thank two anonymous referees, Jim Poterba, Martin Feldstein, Alan Gustman, Jon Gruber, Jerry Hausman, Robin Lumsdaine, Mark McClellan, Jon Skinner, and David Wise for helpful comments. I am also indebted to seminar participants at Dartmouth, the Federal Reserve, Harvard, MIT, the NBER Summer Institute, Syracuse, Virginia, and Wharton for useful suggestions. Arthur Kennickell and Bob Denk at the Federal Reserve provided assistance with the data. Financial support from the National Science Foundation, the Bradley Foundation, and the National Institute on Aging through a grant to the National Bureau of Economic Research is gratefully acknowledged. Any opinions expressed are those of the author and not those of the National Bureau of Economic Research.

(C) 1998 by Andrew A. Samwick. All rights reserved. Short sections of text, not to exceed two paragraphs, may be quoted without explicit permission provided that full credit, including $\odot$ notice, is given to the source. 
New Evidence on Pensions, Social Security, and the Timing of Retirement

Andrew A. Samwick

NBER Working Paper No. 6534

April 1998

JEL Nos. H55, J26

\begin{abstract}
Using a unique dataset that links the economic and demographic information of households with the details of their pension formulas, I estimate the combined effect of Social Security and pension benefits on the probability of retirement in a cross-section of the population near retirement age. The accrual rate of retirement wealth is shown to be a significant determinant of the probability of retirement. Simulations of extensions in pension coverage comparable to those that occurred in the early postwar period can account for one fourth of the contemporaneous decline in labor force participation rates.
\end{abstract}

Andrew A. Samwick

Department of Economics

6106 Rockefeller Hall

Dartmouth College

Hanover, NH 03755

and NBER

samwick@darmtouth.edu 


\section{Introduction}

One of the most profound trends in the American economy since the end of World War II is the decline in the labor force participation rates of older workers. After remaining essentially constant at 65 percent from 1870 to 1937 (Ransom and Sutch, 1988), the labor force participation rates of men over 60 have fallen continuously. ${ }^{1}$ Between 1950 and 1989, male labor force participation rates decreased from 46 percent to 17 percent for those 65 and over and from 87 percent to 67 percent for those 55 to 64 . Over the same period, participation rates for women 65 and over fell slightly from 9.7 to 8.4 percent, and the rapid postwar increase in participation for women 55 to 64 had essentially stopped by the early 1970's. ${ }^{2}$ Since most persons do work for some portion of their adult lives, an important determinant of lower labor force participation is earlier ages of retirement.

A leading explanation for this dramatic decline in labor force participation rates has been the contemporaneous growth of the Social Security program. A product of the New Deal, the retirement portion of Social Security is now an entitlement program that covers nearly all workers and retirees. Total receipts of the Old-Age and Survivors Insurance trust fund in 1995 were \$326.1 billion, compared to $\$ 18.5$ billion in 1950 . In 1995 , there were 26.7 million retired workers who collected average annual benefits of $\$ 8,640$. The corresponding figures for 1950 were 1.8 million and $\$ 3,328 .^{3}$ Chen (1992) and Social Security Administration (1994) report that the share of

\footnotetext{
${ }^{1}$ More recent work by Costa (1997) dates the beginning of the steady decline in male labor force participation to 1880 .

${ }^{2}$ These figures are reported in Special Committee on Aging (1991). Tabulations of the 1996 Current Population Survey presented in Bureau of Labor Statistics (1997) show that there has been little change in these percentages during the 1990s. Lumsdaine and Wise (1990) document the reduction in labor force participation at older ages in more detail.

${ }^{3}$ All figures are from the Social Security Administration (1995). All dollar amounts are in constant 1995 dollars.
} 
aggregate income of households age 65 and over received from Social Security increased from 22 percent in 1958 to 42 percent in 1994.

For over a decade, economists have investigated the importance of higher Social Security benefits as an explanation for earlier retirement using a variety of estimation methods. Surveys of the literature can be found in Atkinson (1987), Quinn, Burkhauser, and Myers (1990), and Diamond and Gruber (1997). Prominent examples include Diamond and Hausman (1984), Burtless and Moffitt (1984), Hausman and Wise (1985), Burtless (1986), Gustman and Steinmeier (1986), and Sueyoshi (1989). The general findings of such studies are that although it is possible to estimate statistically significant relationships between the level of Social Security benefits and the likelihood of retirement at various ages, these estimated relationships typically imply a small economic impact of altering Social Security benefits on the average age of retirement or likelihood of retirement. These results suggest that the trend toward lower labor force participation has other explanations. ${ }^{4}$

Pension coverage and entitlements also grew rapidly since the early 1940s and could just as readily be the underlying cause of the decline in labor force participation. Between 1940 and 1973, the number of retirees receiving pension benefits increased from 200,000 to over 6 million and the number of covered employees rose from 4.1 million to 35 million (Steinberg and Dankner, 1987). Owing to sectoral shifts in employment and sagging economic growth, pension coverage has leveled off at around 50 million workers--about 44 percent of the workforce--in more recent years. Finally, Chen (1992) and Social Security Administration (1994) report that the share of aggregate income of households age 65 and over received from employer-provided pensions (from either

\footnotetext{
${ }^{4}$ One possible explanation for the weak empirical results is the use of cross-sectional variation in Social Security entitlements to identify the effect of Social Security on retirement. International evidence summarized in Gruber and Wise (1997) clearly shows a time-series relationship between reductions in Social Security retirement ages and lower labor force participation rates beyond those ages.
} 
private companies or governments) increased from 14 percent in 1958 to 18 percent in $1994 .^{5}$ More importantly, pension plans are often designed to provide strong incentives for retirement at their specified early and normal retirement ages, as demonstrated in Kotlikoff and Wise $(1987,1989)$. Luzadis and Mitchell (1991) document significant increases in benefit levels and reductions in early and normal retirement ages between 1960 and 1980. Thus, as pensions have become more pervasive, they have also provided stronger incentives to leave the labor force at earlier ages. The standard dataset used in past work on retirement has been the Retirement History Survey (RHS). The RHS is a ten year, biennial panel of eight thousand men aged 58 to 63 in 1969. It contains detailed information on labor supply, earnings, Social Security coverage, and health status that are necessary to model retirement behavior. Its information on employer-provided pensions, however, is limited to whether or not an individual was eligible for a pension upon retirement; there is not enough information to construct a reliable measure of expected pension benefits, much less the differences in pension entitlements for alternate years of retirement. ${ }^{6}$

Stock and Wise (1990a, b) develop an "option value" model of retirement in order to formally incorporate the incentive effects of pensions on retirement. ${ }^{7}$ They show that changes in pension formulas have large effects on the distribution of retirement ages from the firm and that the details of the pension formula play a critical role in identifying the model. In order to analyze

\footnotetext{
${ }^{5}$ Bloom and Freeman (1992) discuss the reasons for the trends in pension coverage. Unlike Social Security, which is a nearly universal program, the fraction of the workforce covered by pensions steadily increases with both age and tenure on a given job. Silverman, Pemberton, and Holmes (1995) report that 56 percent of nonagricultural workers who are 25 to 64, work 1000 or more hours per year, and have at least one year of service are covered by pensions. Similarly, projections in Reno (1993) of the percentage of the elderly who will receive pension benefits in 20-30 years are approximately 75 percent.

${ }^{6}$ Prospectively, the Health and Retirement Survey (HRS) will be the main source of data for retirement studies. The HRS contains excellent data on health status, pension entitlements, and earnings histories. See Gustman, Mitchell, Samwick, and Steinmeier (1997) for a descriptive analysis of the retirement data in HRS.

${ }^{7}$ Other structural models of retirement behavior are Gustman and Steinmeier (1986), Rust (1989), and Berkovec and Stern (1991). See Lumsdaine, Stock, and Wise (1992) for a comparison of several of these methodologies.
} 
pension plans in detail, they draw their sample from the personnel records of a single large firm. The use of personnel records limits their analysis in three ways. First, their sample is not necessarily representative of the working population nearing retirement age, especially those without pensions. Second, personnel records do not contain information on other potential determinants of retirement such as health status, household composition, and wealth. These factors were shown to be important determinants of retirement probabilities in the prior literature on Social Security and retirement. Third, firm reported data can only determine whether an employee left the firm and not whether he left the labor force. The distinction is critical when evaluating the extent to which the growth of pensions has contributed to the decline in labor force participation at older ages.

This paper is one of the first to use a unique dataset that circumvents the tradeoff of detailed pension data versus a nationally representative household survey to study the economic determinants of retirement. The approach here is to link the demographic, employment, and wealth data on households in the Surveys of Consumer Finances (SCF) 1983 and 1986 with information on their pension plans in the companion Pension Provider Survey (PPS). The PPS attempted to interview the plan provider for every worker in the SCF 1983 who reported being covered by a pension. The level of detail was such that pension entitlements can be calculated for each worker for any potential year of retirement. Thus, the SCF and PPS together comprise a panel dataset which contains information on the pension entitlements, retirement behavior, and economic characteristics of a representative sample of workers. This paper utilizes SCF and PPS to determine whether the results of Stock and Wise (1990a, b) generalize from the personnel records of a single large firm to a more representative sample of workers covered by a wider range of pension plans. 
The principal findings of the paper are threefold. First, the significant economic determinant of the probability of retirement is the accrual of retirement wealth due to continued work, not the level of retirement wealth at a point in time. The importance of the retirement wealth accrual is robust to different specifications of the retirement model, but it very much depends on the use of pension wealth data in this analysis. Second, the option value of continued work developed by Stock and Wise $(1990 \mathrm{a}, \mathrm{b})$ is shown to be a parsimonious but comprehensive measure of future retirement incentives in this more representative sample. In a model analogous to theirs predicting departures from the firm, expanding the sample from employees with pensions to all employees decreases the coefficient on the option value by 25 percent (but less than a standard error). In a model predicting transitions out of the labor force, the magnitude of the coefficient is more sensitive to the composition of the sample. Third, changes in pension coverage are simulated to have a substantial effect on the probability of retirement. As much as one fourth of the decline in labor force participation in the early postwar period can be attributed to the contemporaneous growth of pensions.

The organization of the paper is as follows. The next section solves a model of the retirement decision in the presence of pensions and explains the incentive effects of pensions on retirement. Section III describes the data in the SCF and PPS and documents the considerable variation in pension incentives in the workforce. The econometric model of retirement is estimated in Section IV, with special attention to the contribution of the PPS to the analysis. Section V compares the econometric results to previous studies of pensions and retirement that were based on less detailed cross-sections of data. Section VI presents simulations of the effects of changes in Social Security and pension provisions on retirement. There is also a brief concluding section. 


\section{Pension Formulas and the Decision to Retire}

Central to any economic model of retirement decisions is the assumption that an individual will retire when the value of the financial rewards to postponing retirement by a small amount are just offset by the loss in utility that results from the shorter period of higher leisure. Because employer-provided pensions usually provide different benefit amounts based on age, years of service, and final wages, they comprise an important part of the financial incentives to retire in a particular year. This section describes the features of pension plans that give rise to these incentives, and the next documents the considerable heterogeneity in the magnitude of these incentives in the SCF data.

A simple intertemporal model of consumption, $\left\{\mathrm{c}_{\mathrm{s}}\right\}$, and retirement, $\mathrm{R}$, is given by:

$$
\begin{gathered}
\max \int_{s}^{R} \int_{t}^{-\delta(s-t)} u\left(c_{s}, 0\right) d s+\int_{R}^{T} e^{-\delta(s-t)} u\left(c_{s}, 1\right) d s \\
\text { s.t. } A_{t}=\int_{t}^{T} e^{-r(s-t)} c_{s} d s-\int_{t}^{R} e^{-r(s-t)} y_{s} d s-\int_{R}^{T} e^{-r(s-t)} p_{s}(R) d s
\end{gathered}
$$

where $\left\{y_{s}\right\}$ is an exogenous stream of income received while working, $\left\{p_{s}(R)\right\}$ is a stream of retirement benefits that depends explicitly on the date of retirement, $\delta$ is the discount rate, $r$ is the interest rate, and $\mathrm{A}_{\mathrm{t}}$ is current wealth at time $t$. The second argument in the utility function accounts for the (positive) effect of retirement leisure on utility.

A continuous time framework is assumed so that the maximand is continuous in the date of retirement. If it is also assumed that pension benefits are a differentiable function of the retirement date (both of these assumptions will be dropped below), the first-order condition for $\mathrm{R}$ is:

$$
e^{-\delta(R-t)}\left[u\left(c_{R}, 1\right)-u\left(c_{R}, 0\right)\right]=\lambda e^{-r(R-t)}\left[\left(y_{R}-p_{R}(R)\right)+\int_{R}^{T} e^{-r(s-R)} p_{s}^{\prime}(R) d s\right]
$$


where $\lambda$ is the shadow value of the constraint in (1) and can be interpreted as the marginal utility of wealth at date $t$. The left side of the equation is the gain in utility that results from a marginal decrease in the retirement date. ${ }^{8}$

The right side is the utility value of the change in financial resources that results from a marginal increase in the retirement date. The first term in brackets is the difference between earnings and retirement benefits at $\mathrm{R}$; this is the immediate financial incentive to delay retirement. The second term is the present value at $\mathrm{R}$ of the increase in retirement benefits that results from a marginal delay in the retirement date. Pension formulas that provide strong incentives to delay retirement will have larger values of this term. The tendency for pension benefits to increase substantial for greater years of service is known as "backloading," and it has been widely documented in employer-provided pensions (e.g., Kotlikoff and Wise (1987)).

Equation (2) suggests that an important consideration in the decision to retire is the increase in pension wealth that results when retirement is delayed. In order to recast this quantity into one that can be utilized in an empirical model in which individuals are observed at discrete ages, it is useful to consider the actuarial present value of the flow of pension benefits conditional on an employee working through age $a$ and then retiring:

$$
A P V(a)=\int_{a}^{T} e^{-r(s-a)} p_{s}(a) d s
$$

and to calculate the increment to (the current value of) retirement wealth that accrues if retirement is delayed from age $a-1$ :

\footnotetext{
${ }^{8}$ The notation in (2) assumes $c_{R}$ is the same regardless of whether the individual is retired at $R$. This assumption is valid if the utility function is separable in leisure and consumption. Even if separability is not assumed, the left side of (2) will be positive as long as the marginal utility of leisure in retirement is positive.
} 


$$
\begin{aligned}
I(a) & =A P V(a)-e^{r} \operatorname{APV}(a-1) \\
& =\int_{a}^{T} e^{-r(s-a)} p_{s}(a) d s-\int_{a-1}^{T} e^{-r(s-a)} p_{s}(a-1) d s \\
& \approx \int_{a}^{T} e^{-r(s-a)}\left[p_{s}(a)-p_{s}(a-1)\right] d s-p_{a-1}(a-1)
\end{aligned}
$$

$\mathrm{I}(\mathrm{a})$ is analogous to wage payments in the sense that the worker's lifetime wealth is augmented by this amount for working at age $a$; it is a form of compensation for being employed at the job in that year. Adding the wages actually paid to I(a) would yield a one-year analogue to the right side of (2). In the subsequent analysis, I(a) will be referred to as the pension wealth accrual (or retirement wealth accrual, if Social Security is included).

Since all pensions are (weakly) increasing in the level of wages in each year, workers with higher values of $y_{a}$ will tend to have higher values of $\mathrm{I}(\mathrm{a})$ regardless of the details of the pension formula. Scaling by $\mathrm{y}_{\mathrm{a}}$ focuses on the differences in pension accruals inherent in the pension formulas rather than differences in wages. The quantity $\mathrm{R}(\mathrm{a})$, defined as:

$$
R(a)=I(a) / y_{a}
$$

thereby allows comparisons to be made between the retirement incentives provided by pensions for workers of different wage levels.

Figure 1 shows a schedule for a hypothetical $\mathrm{R}(\mathrm{a})$ that is typical of defined benefit pension formulas in the PPS. ${ }^{9}$ The features of this plan are as follows. Final average pay is determined by the nominal average of the last five years of wages. The worker earns a benefit entitlement of one percent of final average pay for each year of service. As was the case in 1983, the worker's benefit entitlements are vested after 10 years of service. Early retirement benefits can be taken immediately at any age after the early retirement age (ERA) of 55 as long as the worker has 20 years of service.

\footnotetext{
${ }^{9}$ The calculations for I(a) and R(a) approximate the continuous time expressions with discrete sums of benefits received at each integer age under the reasonable assumption that the value of the payment is fixed over the year.
} 
The worker in Figure 1 began work at age 31, so he would have 25 years of service at age 55 and be eligible for early retirement. Normal retirement benefits can be taken at the normal retirement age (NRA) of 65, or at any age after 60 as long as the worker is vested.

The two large spikes in the graph occur at the ages when the worker is first eligible for early and normal retirement benefits. Before the ERA, the worker is entitled only to vested deferred benefits that are subject to actuarially fair reduction for every year they are received before the NRA. Since final average pay is not indexed to inflation, vested deferred benefits do not amount to much wealth for young workers. Provided the worker remains with the firm until the ERA, benefits are available immediately at an actuarially favorable reduction rate of 3 percent per year for each year they are taken before the NRA. The change in reduction factors determines the size of the spike at the ERA; in this case, the increase in pension wealth is equal to twice the annual wage. The smaller spike at age 60 , which is equal to about 60 percent of the wage that year, is the result of the option of taking normal retirement benefits before the NRA if benefits are already vested.

The salient feature of Figure 1 is that retirement behavior in years near the ERA and NRA should be heavily influenced by the opportunity to get large increments to lifetime wealth by working until those ages rather than retiring immediately. As suggested by equation (2), it would be unusual to observe this worker retiring at age 54 given the very high financial rewards to working just one more year--the increment to utility resulting from an extra year of leisure would have to exceed twice the value of the wage.

The key to analyzing the effect of pensions on retirement in a cross-section of workers is measuring the different pension incentives for remaining with the current employer for each worker's pension and relating them to actual retirement transitions. The capacity to account for the variation in the retirement wealth accrual patterns confronting a broad sample of workers is the 
chief contribution of the PPS to the study of retirement behavior. The next section describes the cross-section of workers in the SCF at risk for retirement and documents the considerable variation in retirement wealth accruals implied by their pension formulas.

\section{The Surveys of Consumer Finances and Pension Provider Surveys}

The Survey of Consumer Finances 1983 (SCF) was designed to be the most comprehensive survey of household wealth conducted to date. In recognition of the growing financial importance of pensions in the economy, the Pension Provider Survey (PPS) was conducted with the households' pension sponsors to obtain the full summary plan description of each plan. ${ }^{10}$ Because the SCF also contains detailed demographic and economic data and a re-interview survey was performed in 1986, it is possible to use the two datasets to study retirement behavior in the years between 1983 and 1986. This section describes the sample extract used and the construction of the relevant variables for the subsequent analysis.

The full SCF is comprised of 4,103 households in 1983. Of these, 438 are from a sampling frame selected from high income tax returns and the rest are from an area-probability sample designed to be nationally representative of the population. In 1986, 2,822 households were reinterviewed, providing a panel of observations whose interim labor market experience can be analyzed. ${ }^{11}$ The sample used below includes all respondents and spouses in such households between the ages of 50 and 69 and working full-time (at least 20 hours per week) in 1983. Individuals were excluded if they reported being self-employed or working in the military services

\footnotetext{
${ }^{10}$ According to the Flow of Funds Accounts (Board of Governors, 1990), pension fund reserves accounted for $\$ 1.392$ trillion or 13 percent of the $\$ 11.060$ trillion of household sector net worth in 1983 . The corresponding percentage was less than 2 percent in 1945.

${ }^{11}$ Avery, Elliehausen, Canner, and Gustafson (1984a, b) describe the sample construction of the 1983 survey. Avery, Elliehausen, and Kennickell (1987) discuss the re-interview process and the general quality of the data in the 1986 survey.
} 
as their main occupation. Individuals were also excluded if they reported being covered by a pension but were not present in the PPS. ${ }^{12}$

After imposing these restrictions, the sample contains 525 individuals. Table 1 presents means and standard deviations of the explanatory variables other than retirement variables that will be used in the econometric analysis. For comparison, analogous statistics are presented from the first wave of the Health and Retirement Study (HRS). The HRS is comprised of individuals age 50 to 62 in 1992 and will be the dataset used in future retirement studies as more waves are made publicly available. Both sets of statistics are weighted to represent the population at large. The two samples are similar in the proportion female, the proportion married, and years of education.

Despite the different age ranges covered, the mean age is also similar across the surveys. The fraction of households reporting poor health (compared to fair, good, or excellent) is 1.1 percent in the SCF, which is about half of the 2.0 percent that report poor health in the HRS. In the SCF, 65.4 percent of the households are covered by a pension, compared to 69.8 percent in the HRS. ${ }^{13}$

The SCF's oversampling of high-income households is evident in the mean earnings of $\$ 22,028$, compared to $\$ 17,724$ in the HRS. This difference in sampling design, along with the difference in the age distribution and the earlier time period of the sample, may also contribute to the two extra years of tenure in the SCF. The HRS oversamples ethnic minorities. The fraction who report a racial group other than white is 11.8 percent in the SCF, compared to 17.6 percent in the HRS. On

\footnotetext{
${ }^{12}$ About 100 observations are censored in this way in the sample used for estimation. In 70 percent of the cases, contact was made with the pension provider but the survey could not be coded. As discussed in Samwick (1993), response rates for public sector and educational institutions were all around 90 percent or more. Response rates for firms with 100 or more employees were over 70 percent, while response rates for private firms with fewer than 100 employees were slightly over 50 percent. The effect of this sample restriction is therefore to over-represent public sector workers relative to private sector workers.

${ }^{13}$ The exclusion of households that report pension coverage in the SCF but who are not found in the PPS biases the SCF number downward.
} 
balance, the SCF sample is considerably smaller than the HRS but not too dissimilar in its demographic and economic makeup. ${ }^{14}$

For Social Security, the SCF reports employment information on the current job and up to three previous ones for each individual. The re-interview survey in 1986 reports information on the job held in 1986 and the circumstances, if any, under which the 1983 job was terminated. The dates of employment, industry, occupation, Social Security coverage, and final wages are given for each job. Cross-sectional age-earnings profiles were estimated by sex, race, and occupation using the Current Population Surveys for 1983-1986, and the coefficients were used to impute wage histories on all jobs. ${ }^{15}$ Given the wage histories and the published benefit laws for Social Security, the benefits can be computed for each individual for each year in which he or she could retire. ${ }^{16}$

It is important to acknowledge at the outset that the use of imputed wage histories fail to capture much of the interesting variation across households in their expected Social Security benefits. The Social Security benefit formula is essentially a weighted average of indexed earnings over the entire work life. Differences across workers due to differences in average wage levels, age, and marital status are captured, but the details of spells outside the labor force, transitory shocks to earnings, and earnings early in the work life are not observed. Combined with the absence of major changes to the Social Security formula for workers over age 50 during the sample period, it is not

\footnotetext{
${ }^{14}$ A shortcoming of the SCF sample in 1983 is that it does not contain information on health insurance coverage that may also affect the retirement decision. Madrian (1993) observes that the average age of retirement at firms with postretirement health insurance is 0.5 to 1 year lower than at firms without post-retirement health insurance.

${ }^{15}$ This estimation and imputation procedure is described in Samwick (1993).

${ }^{16}$ Social Security is assumed to start immediately for workers over age 62 and at age 62 for workers younger than age 62. The Social Security benefits for married workers are more complicated. If the primary insurance amount (PIA) of one spouses is less than half that of the other spouse, the lower earning spouse is assumed to be a dependent spouse and therefore have no Social Security wealth while the higher earning spouse has the benefits for a dependent spouse and widow included in Social Security wealth. If the PIA of the lower earning spouse is greater than half that of the higher earning spouse, then the lower earning spouse has Social Security wealth equal only to the value of the retirement benefits that will be collected while the higher earning spouse is alive. The higher earning spouse will have the value of the subsequent widow benefits included in Social Security wealth.
} 
possible to use these data to make precise inferences about the effect of historical changes in Social Security program on retirement patterns.

For pensions, the PPS specifies the exact pension formula for each covered individual. For defined contribution plans, the PPS gives the rates of mandatory, voluntary, and matching contributions as well as the formulas for accumulating contributions, vesting, and full receipt of the employer's contributions. For defined benefit plans, all formulas for computing vested deferred, early, normal, and late retirement benefits are given. Each formula may have its own vesting schedule and include separate definitions of years of service, final average pay, or Social Security integration amounts. The full history of plan revisions, including the changes in many plans in the wake of ERISA, is also included. "Window Plans," such as the one described in Stock and Wise (1990b), appear to be included only if they are in effect at the time of the PPS interview. Using the information for the current job and the imputation method described above to fill in the wage history with the employer, it is possible to compute the pension benefits for each individual for any year in which he or she could retire. ${ }^{17}$

Table 2 presents summary statistics on Social Security and pension wealth levels. Social Security wealth is the actuarial present value of all Social Security benefits the individual would receive if he or she retired in the current year. Pension wealth is defined analogously. ${ }^{18}$ Added together, pension and Social Security wealth correspond to APV(a) as defined above. The top panel of the table shows that the average worker has about $\$ 47,000$ in Social Security wealth and close to

\footnotetext{
${ }^{17}$ All pension benefit streams are assumed to commence at the earliest possible date. This will be the current year for employees eligible for early or normal retirement benefits and an age specified in the pension formula for those entitled to vested benefits.

${ }^{18}$ The estimates of Social Security and pension wealth assume an inflation rate of 4 percent and an economy-wide real wage growth rate of 1.5 percent, corresponding to the Social Security Administration's II-B (intermediate) assumptions from this time period. For the purpose of discounting, the standard life tables by age and gender from Faber (1982) and a real interest rate of 3 percent are used.
} 
$\$ 30,000$ in pension wealth. The median Social Security wealth is just slightly lower than the mean, but the median pension wealth is zero. This reflects the third of the population not covered by pensions plus some individuals covered by pensions but not yet vested in 1983 .

To get a better idea of the distribution of benefits, the bottom panel of Table 2 excludes all observations who are not eligible for both pensions and Social Security. The figures for Social Security are slightly higher, and the mean for pension wealth is now about $\$ 40,000$ or 75 percent of Social Security wealth. Median pension wealth is only about $\$ 18,000$; nonetheless, the medians for both types of retirement wealth are considerably higher than that of financial assets, suggesting that most workers will rely primarily on their pensions and Social Security to finance retirement consumption. Additionally, the standard deviation for pension wealth is $\$ 65,000$, or nearly three times that of Social Security wealth. These statistics show that pension wealth is far more concentrated at the top of its distribution than is Social Security wealth. ${ }^{19}$ The right side of Table 2 scales retirement wealths by the wage, and this tends to smooth out the differences in the two distributions.

Also presented in Table 2 are the accrual rates for pension and Social Security wealth--the counterparts to I(a) and R(a) defined above. The bottom panel of Table 2 shows that pension accruals are much more dispersed than pension wealth; the coefficient of variation of the former is 6.32 while that of the latter is 1.68 . By comparison, the distribution of Social Security accruals is far less diffuse.

\footnotetext{
${ }^{19}$ One reason why the average Social Security wealth is higher despite universal pension coverage and some large outliers for pensions in this subsample is the fact Social Security benefits are indexed to inflation whereas fewer than 3 percent of defined benefit pension plans contractually adjust benefits for inflation. Allen, Clark, and McDermed (1992) report that about one quarter of defined benefit pension plans in medium and large firms provided some ad hoc increase in benefits between 1983 and 1987. The probability of receiving such an increase is not incorporated in the calculations of pension wealth.
} 
Another perspective on the diversity of pension incentives is provided by Figure 2. For each plan in the PPS, the value of $\mathrm{R}(\mathrm{a})$ is computed for a worker with average wages and coverage under the pension since age 31 for all potential retirement ages. Using the sample weights of the individuals covered by each plan, the distribution of $\mathrm{R}(\mathrm{a})$ is formed for each age. The mean, 10th percentile, and 90th percentile of these distributions are plotted. Even controlling for tenure, the average accrual graph shows substantial variation by age. Additionally, at every age there are at least 10 percent of the workers with zero or negative accruals and another 10 percent with accrual rates two to three times the average.

It is important to note in the interpretation of Figure 2 that the precise pattern of spikes in the weighted average pension accrual profiles is dependent on the assumption that the worker is hired at age 31 in all cases. While it is true that firms often make available early retirement at ages of 55 and 60, in many cases (such as Figure 1) a worker's eligibility for early retirement benefits depends on his tenure at the firm in addition to his age, with longer tenure workers getting the incentives at younger ages. Woodbury (1997) traces this pattern to the firm's desire to smooth out replacement rates across workers while still giving higher benefits for longer tenures. The particular worker in Figure 2 is hired at a young enough age that he is eligible for early retirement at the earliest possible age in most cases. Age 31 corresponds to approximately the $25^{\text {th }}$ percentile of the age of hire in this sample for jobs in progress in 1983 . The $50^{\text {th }}$ and $75^{\text {th }}$ percentiles are 39 and 46, respectively. The average incentives facing the actual distribution of tenures in the population is substantially smoother by age than that in Figure 2. 


\section{A Basic Model of the Probability of Retirement}

The previous section establishes that retirement incentives in the PPS are often large and vary substantially in the population. This section estimates an econometric model of the retirement decision that assesses the degree to which these incentives affect retirement. Two aspects of the analysis receive special consideration. The first is the contribution of the PPS to the study of retirement beyond what was available in household surveys that did not include pension formulas. The second, addressed in the next section, is the contribution of the nationally representative SCF sample to the study of the effect of pensions on retirement beyond what is available in samples of personnel records, where the pension formula at a limited number of firms can be directly observed. Retirement will be defined in two ways in the econometric analysis. For consistency with Stock and Wise (1990a, b), retirement will first be defined as any termination of employment at the firm where the employee worked in the 1983 survey, regardless of whether it was voluntary or resulted in a total withdrawal from the labor force. Their use of personnel records implied that they could not define retirement based on what the employee chose to do after leaving the firm. However, any attempt to relate changes in pension provisions to the decline in labor force participation must condition on whether the employee leaves the labor force in addition to the firm at which he worked in the initial sample. Consequently, the second definition of retirement includes only transitions from the 1983 job in which the employee leaves the labor force and does not return by 1986 , citing a voluntary reason for leaving the 1983 job. $^{20}$

The disadvantage of using the SCF to study retirement is the relatively small number of observations. This disadvantage is compounded by the comparatively short panel of three years in

\footnotetext{
${ }^{20}$ In past studies, retirement has alternatively been defined by a discontinuous drop in hours worked (e.g., Burtless and Moffitt (1984)) and a change in the self-reported retirement status (e.g., Hausman and Wise (1985)). Other studies have more formally attempted to distinguish between full and partial retirement (e.g., Rust (1989) and Sueyoshi (1989)). Ruhm (1990) discusses the importance of partial retirement and "bridge" jobs between career jobs and full
} 
the SCF relative to the ten year panel in earlier studies like the Retirement History Survey. The small size of the sample necessitates a flexible specification of the impact of economic variables on retirement. All retirement models are estimated essentially by comparing the observed retirement behavior in a sample of workers with the value of a function of their economic characteristics. The most straightforward example is a probit model.

The likelihood function for the probit in this sample is:

$$
L(X, y, \beta, \sigma)=\sum_{i=1}^{N} \sum_{t=1}^{T_{i}}\left[\left(1-y_{i t}\right) \log \left(\Phi\left(-\frac{\beta^{\prime} X_{i t}}{\sigma_{i t}}\right)\right)+y_{i t} \log \left(\Phi\left(\frac{\beta^{\prime} X_{i t}}{\sigma_{i t}}\right)\right)\right]
$$

where $\Phi(\mathrm{z})$ is the cumulative distribution function for a standard normal evaluated at $\mathrm{z}, i$ indexes the individual, $t$ indexes the year of observation, $\mathrm{T}_{\mathrm{i}}$ is the number of years at which the individual is observed before leaving the 1983 firm, and $\mathrm{y}_{\mathrm{it}}$ is an indicator variable which is one if individual $i$ retires in year $t$. Explanatory variables are included additively in the vector $\mathrm{X}_{\mathrm{it}}$. The vector $\beta$ is the set of parameters to be estimated. Note that $\sigma$, the variance of the error term, is subscripted by both $i$ and $t$ to allow for heteroskedasticity and serial dependence. In the standard model, $\sigma$ is normalized to unity.

The discussion of the incentive effects of pensions in Section II implies that, at a minimum, workers who have higher retirement wealth accruals should be less likely to retire in the current year. If I(a) is one of the variables in X, it should have a negative coefficient. Similarly, high wages should discourage retirement because the opportunity cost of leisure is higher. As Figure 1 suggests, a high value of $\mathrm{I}(\mathrm{a}+1)$ should also discourage retirement at age $a$, though not by as much as the same value of I(a). High future retirement wealth accruals should also be expected to reduce the probability of retiring in the current year.

retirement. 
Stock and Wise (1990a) develop an "option value" model of retirement that compactly incorporates both current and future retirement wealth accruals. The option value of not retiring in the current year is the possibility of retiring in a later year, when the APV of retirement wealth may be substantially higher. Against the higher wealth must be balanced the foregone leisure during the years of continued work. Their estimation framework was a maximum likelihood estimation of parameters of an indirect utility function that captured this economic tradeoff and allowed for serial dependence and age-related heteroskedasticity in the error terms.

As a reduced form alternative, the option value of retirement can be calculated based on assumed parameter values and used as an explanatory variable in $\mathrm{X}_{\mathrm{it}}{ }^{21}$ In year $t$, the option value calculation for each individual who is age $a$ is:

$$
G_{t}\left(R^{*}\right)=\sum_{s=t}^{R^{*}-1} \delta^{s-t} \pi(s \mid t) E_{t}\left(y_{s}^{\gamma}\right)+\sum_{s=R^{*}}^{T} \delta^{s-t} \pi(s \mid t) E_{t}\left[k \cdot p_{s}\left(R^{*}\right)\right]^{\gamma}-\sum_{s=t}^{T} \delta^{s-t} \pi(s \mid t) E_{t}\left[k \cdot p_{s}(t)\right]^{\gamma}
$$

In this expression, $\delta$ is a discount factor, $\gamma$ is a parameter of relative risk aversion, $\pi(\mathrm{s} \mid \mathrm{t})$ is the probability of someone age $a$ in year $t$ surviving to year $s$, and the expectation $\mathrm{E}_{\mathrm{t}}(\bullet)$ denotes the expected value of future income $\left\{y_{s}\right\}$ and retirement benefit streams $\left\{p_{s}(R)\right\}$, with the latter conditional on retirement in year $R . \mathrm{R}^{*}$ is the optimal retirement date determined by considering all possible dates between $t$ and $\mathrm{T}$ and selecting the one that maximizes the right-hand side of the equation.

The first term on the right-hand side of the equation represents the utility of income received between the current date, $t$, and the chosen date of retirement, $\mathrm{R}^{*}$. The second term represents the utility of retirement benefits received between the date of retirement and the date of death, T. The means through which the added leisure during retirement increases utility is by multiplying the

\footnotetext{
${ }^{21}$ In my attempts to estimate the parameters of the option value model on the SCF sample, the parameters for the value of leisure in retirement $(\mathrm{k})$ and the discount rate $(\delta)$ could not be simultaneously identified with any precision.
} 
retirement income stream by a factor $\mathrm{k}$, where $\mathrm{k}>1$. The option value is calculated by subtracting the third term, which is the utility of retirement benefits received between the current date and the date of death if retirement occurred immediately. As discussed in Section II, added years of service will generally make $\mathrm{p}_{\mathrm{s}}\left(\mathrm{R}^{*}\right)>\mathrm{p}_{\mathrm{s}}(\mathrm{t})$, and the difference could be quite large if the period between $t$ and $\mathrm{R}^{*}$ includes the early retirement age for the pension and therefore a very large pension wealth accrual. This option value represents the financial incentives to delay retirement from the current date to the most financially advantageous date to retire in the future. Other things equal, a higher option value should reduce the probability of retirement in the current year.

Plausible values for $\gamma$ and $k$ that are consistent with those in Stock and Wise (1990a) are 0.75 and 1.5 , respectively. A value of 1 for $\gamma$ would imply risk-neutrality; i.e. only the present value of future payments would be relevant. A value of 0.75 implies that the individual would prefer that a given present value of income and benefits be distributed evenly over all years. The chosen value of $\mathrm{k}$ implies that individuals would be indifferent between working to earn three dollars and retiring to collect only two dollars. The value of $\delta$ has been set so that future streams of payments are discounted at a 3 percent real discount rate.

Table 3 presents the results of the probit models specified in equation (6) using three different measures of the retirement incentives provided by Social Security and pensions. Retirement is broadly defined as any termination of employment at the employer from the 1983 survey. The estimates in the first column use the calculated option value of retirement from equation (7) as an explanatory variable. As predicted by the theory in Section II, its coefficient is negative, and it is statistically different from zero at the 1 percent significance level. ${ }^{22}$ The option

\footnotetext{
${ }^{22}$ The standard errors for the probits are calculated according to the method in Rogers (1993). In addition to being robust to heteroskedasticity, they allow for correlation in the error terms across observations of the same individual in different years and across different members of the same household in any year.
} 
value calculation incorporates the current year's wage like any other income payment. The insignificant coefficient on the wage in this specification indicates that it has no further effect on retirement beyond its impact on the option value. The coefficient on the level of retirement wealth is positive and statistically significant. By contrast, the coefficient on financial assets is over 100 times smaller and insignificant. These estimates suggest that there is no tendency for those with higher financial wealth levels to use it to enjoy longer periods of retirement, but there is some evidence that higher values of retirement wealth lead to a higher probability of retirement.

Among the demographic variables, only age is significantly related to the probability of retirement, with those at higher ages more likely to retire. By comparison, the point estimate on tenure is negative, one-third the magnitude, and not statistically significant. The point estimate on poor health is large--equivalent in magnitude to being over ten years older--but the limited variation in the health status variable makes the estimate insignificantly different from zero.

The models in the other two columns of Table 3 use progressively less information about retirement incentives to predict retirement. The second column uses only the present value of retirement wealth and the current year's accrual of retirement wealth. This corresponds to entering APV(a), I(a), and y separately as explanatory variables. The coefficient on the retirement wealth accrual is negative and statistically significant at the 1 percent level. ${ }^{23}$ Computed at the means of the explanatory variables, the marginal effect of an additional thousand dollars of retirement wealth accrual is to decrease the probability of retirement by 0.35 percentage points. The coefficient on

\footnotetext{
${ }^{23}$ The estimates in Table 3 omit five individuals who have retirement wealth accruals greater than $\$ 230,000$ during the sample period. If they are included, the results are driven entirely by two individuals who retire nonetheless. The root of the problem in both cases is the self-reported measure of the number of years the individual has been working for the same firm. For example, one is age 60 and claims to have 9 years experience. Cliff-vesting at 10 years of experience and a wage over $\$ 150,000$ generate the large pension accrual. If actual experience is 10 years already, then the worker has actually responded to the large accrual as model predicts by staying with the firm through the current year and then retiring. Ideally, the possibility of this measurement error could be taken into account directly in the maximum likelihood specification.
} 
current wages is negative but not statistically significant. In this specification, the coefficient on retirement wealth is still positive but insignificant, as is that on financial assets.

This model can also be estimated by including pension wealth and accruals separately from Social Security wealth and accruals, rather than imposing the restriction that their coefficients are equal. The coefficients on both Social Security and pension wealth are unchanged and remain insignificant. The coefficient on the Social Security wealth accrual falls to -0.0161 and is insignificant. The coefficient on the pension wealth accrual changes very slightly to -0.0222 and is statistically significant at the 1 percent level. The p-value for the test of equality of the accrual coefficients is 0.80 . In this sample, the identification of the retirement wealth accrual coefficient comes more from the variation in pensions than from the variation in Social Security. This is to be expected based on both the wide heterogeneity in pension formulas documented in Section III and the imputations that were necessary in the construction of the Social Security variables.

The estimates in the third column correspond to the type of model that is found in the prior retirement literature that lacked detailed information on pension wealth and accruals. The measures of retirement wealth and accruals contain only Social Security information. Pensions are included only through an indicator variable for pension coverage. The point estimate on the retirement wealth accrual is slightly lower when it excludes the pension wealth accrual, but it is not significantly different from zero. The coefficient on pension coverage is negative, suggesting that workers with pensions are less likely to leave their jobs, but the coefficient is only the size of its standard error. This insignificant finding is not surprising in light of the estimates in the first two columns. Having a pension when the option value is high will discourage retirement, but having a pension when the option value is low will encourage retirement. 
Table 4 re-estimates the models from Table 3 using the more narrow definition of retirement that includes only transitions in which the employee leaves the labor force and does not return by 1986, citing a voluntary reason for leaving the 1983 job. In the specification that uses the option value calculation, its coefficient is almost unchanged at -0.1466 but is now significant at only the 15 percent level. The coefficient on retirement wealth also loses most of its statistical significance. The coefficient on age is larger and more statistically significant than in Table 3, but the marginal effect of another year of age is roughly 0.45 percentage points at the sample means in both specifications. The coefficient on poor health is now only three times that of age. The coefficient on tenure switches from negative to positive but is still insignificant. As in Table 3, the coefficients on education, married, and race are negative and insignificant, and that on financial assets is positive and insignificant. Net Equity in housing has a small but significantly negative effect on retirement in both specifications. Unlike Table 3, the coefficient on female is now positive and about 50 percent larger than its standard error, suggesting that women are somewhat more likely to retire though no more likely to leave their job without leaving the labor force entirely.

The next two columns use the one year accruals in retirement wealth rather than the calculated option value. In the specification that uses pension data to construct retirement wealth, the coefficients on the retirement wealth accrual and the wage level are both negative and statistically significant at the 1 percent level. The coefficient on the level of retirement wealth is positive but insignificant, and the coefficients on the other variables are similar to those in the first column. In the specification that excludes pension wealth and accruals, the coefficient on the retirement wealth accrual is about 50 percent larger than in the specification that includes pension wealth, but its standard error is so large that the new estimate is not significantly different from zero or the estimate in column 2. The coefficient on retirement wealth is negative but insignificant. The 
coefficient on the dummy variable for pension coverage is still insignificant but is now estimated to be positive. Having a pension seems to discourage leaving the firm, but given a departure, having a pension encourages making the transition into retirement.

The models in Tables 3 and 4 assume that the effect of age on the probability of retirement is linear. Figure 3 graphs the predicted hazard rates at each age from the option value model and the retirement wealth accrual variable (from Table 4) against the actual retirement hazard in the data. The hazard rate at a particular age is the probability of being retired at that age conditional on not being retired at any prior age. Both models clearly fail to predict the sharp increase in the retirement hazard at age 62, the date at which Social Security benefits can first be collected. As discussed in Lumsdaine, Stock, and Wise (1992), this inability to predict the large spike at age 62 is typical of cross-sectional models of retirement. This discrepancy could be "corrected" by including indicator variables for all age levels as explanatory variables. The predicted hazard rates would then trace out the mean retirement rates by age, with variation around the mean provided by the other variables in the model.

Estimates of the models in Table 4 with a full set of age variables rather than the linear term yield coefficients of -0.1594 on the option value and -0.0256 on the retirement wealth accrual, with p-values of 0.208 and 0.011 , respectively. ${ }^{24}$ The corresponding estimates for the models in Table 3 are -0.1707 and -0.0220 , with p-values of 0.015 and 0.001 . The estimated coefficients are therefore not greatly affected by tailoring the specification to match the age-specific hazard rates in Figure 3, and they do not lose much of their statistical significance. In all cases, the test of the null hypothesis

\footnotetext{
${ }^{24}$ See Appendix B for tables containing the results of the alternative specifications of the retirement probits discussed in the remainder of this section.
} 
that all the age effects are jointly equal to zero cannot be rejected at the five percent level, although the dummies for age 62 and age 65 are individually significant. ${ }^{25}$

The sample of households used to estimate retirement in the SCF is unusual in two respects. The first is that it includes women in addition to men, whereas most previous studies focused only on the retirement behavior of men. In the SCF sample, imposing this restriction results in a sample size of 312 employees and 836 observations. For the specifications from Table 3, the coefficient on the calculated option value is -0.1607 with a p-value of 0.002 , and the coefficient on the retirement wealth accrual is -0.0150 with a p-value of 0.013 . In both cases, the estimates are within a standard error of the values in Table 3. The second unusual aspect is the presence of the high-income sample. When the high-income households are excluded, the sample contains 403 employees and 1061 observations. For the specifications from Table 3, the coefficient on the calculated option value is -0.2090 with a p-value of 0.042 . The coefficient on the retirement wealth accrual is -0.0449 with a p-value of 0.000 . If instead the observations are weighted by the sample weights used in Tables 1 and 2, the coefficient on the calculated option value is -0.2438 with a p-value of 0.000 , and the coefficient on the retirement wealth accrual is -0.0337 with a p-value of 0.001 . The retirement incentive effects appear to be larger for those with lower income than for those in the high-income sample. $^{26}$

\footnotetext{
${ }^{25}$ Another way to account for the age-specific retirement rates is by estimating a hazard model such as those in Diamond and Hausman (1984) and Hausman and Wise (1985). The hazard model takes the underlying hazard rate by age as given and constrains the effect of the other covariates to simply multiply the baseline hazard at each age. The coefficients on the calculated option value and retirement wealth accrual are both negative, with p-values of 0.053 and 0.010 , respectively.

${ }^{26} \mathrm{~A}$ study of job transitions in panel data must control for possibly nonrandom attrition of households between the original 1983 survey and the 1986 reinterview survey. Appendix A develops a bivariate version of the retirement probit in which full-information maximum likelihood is used to control for the possibility of sample selection. Because the estimated parameters in the retirement equation are similar to those reported here, the univariate specification will be maintained.
} 
The estimates in Table 3 and 4 establish that the retirement wealth accruals have statistically significant effects on the decision to retire. This result obtains using the current year's retirement wealth accrual and the calculated option value of retirement. When data on pension wealth and accruals are not used, as many past studies of retirement were constrained to do, the impact of retirement wealth accruals on the decision to retire is roughly the same in magnitude but not statistically different from zero. The dummy variable for pension coverage in that specification is insignificant for both definitions of retirement and differs in sign across the two definitions.

\section{Comparison to Previous Option Value Estimates}

The SCF data can also be used to assess the generalizability of the results in Stock and Wise (1990a) and their subsequent work. As discussed in the Introduction, there are three dimensions along which the SCF sample provides more variation than the Stock and Wise (1990a) sample of personnel records from a single large firm. The first is that personnel records do not contain information on wealth held outside of the pension plan or demographic characteristics of the employee other than age. The reduced form specifications estimated in Tables 3 and 4 also included demographic variables for tenure, education, gender, race, marital status, and poor health. All were estimated to be insignificant, suggesting that their omission from personnel records is not critical. Financial assets were estimated to have an insignificant effect on retirement, and housing net equity had a negative effect on retirement that was statistically significant but small in magnitude.

The second potential limitation of personnel records is that they cannot distinguish between departures from the firm that lead to withdrawal from the labor force and those that do not. Because transitions out of the labor force occur with less frequency than do departures from the initial sample firm, the standard marginal effect calculation needs to be scaled by the predicted probability 
of retirement in order to compare the effect of pensions on retirement across two different dependent variables. For any variable $j$ in the probit model, this statistic is:

$$
\frac{\partial \Phi\left(\beta^{\prime} \bar{x}\right) / \partial \bar{x}_{j}}{\Phi\left(\beta^{\prime} \bar{x}\right)}=\frac{\phi\left(\beta^{\prime} \bar{x}\right) \beta_{j}}{\Phi\left(\beta^{\prime} \bar{x}\right)}
$$

where $\phi(\mathrm{z})$ is the probability density function of the standard normal evaluated at $\mathrm{z}$ and the bar over $x$ denotes the sample average of the variable. For the option value variable, this statistic is 0.283 for the broad definition of retirement in Table 3 and 0.346 for the narrow definition in Table 4 . For the retirement wealth accrual variable, this statistic is 0.039 for the broad definition and 0.056 for the narrow definition. Based on these comparisons, the estimates in Stock and Wise (1990a) based on the broad definition of retirement likely understate the full impact of pensions and Social Security on retirement from the labor force.

The third difference is that there is less variation in the budget constraints and preferences across observations in a sample of salesmen at a given firm than in the SCF. It may be that the workers at the particular firm are not representative of the population of workers that is at-risk for retirement. As a first step in investigating the consequences of this restriction, Table 5 excludes all employees who do not have both pension and Social Security wealth. The first two columns define retirement as all departures from the firm. The coefficient and statistical significance of the retirement wealth accrual are virtually unchanged. The coefficient on the option value is about one third larger in magnitude but within a standard error of the original estimate, and it remains highly significant. The last two columns define retirement as departures from the labor force. The coefficient on the retirement wealth accrual increases in magnitude by one fifth and is statistically significant at the 1 percent level. The coefficient on the option value triples and becomes statistically significant at the 1 percent level. The significance of the results in Tables 3 and 4 is therefore not an artifact of differences between those with pensions and those with no pensions. 
Quite the contrary, selecting the sample according to pension coverage tends to overstate the importance of pension incentives on retirement.

\section{By How Much Do Pensions and Social Security Affect Retirement?}

The estimates in Tables 3 through 5 show that both the one-year accrual in retirement wealth and the option value of retirement have statistically significant, negative effects on the probability of retirement. In order to determine the economic content of these results, this section uses the estimates from Table 4 to simulate the change in labor force participation rates in response to changes in Social Security and pensions. As in the estimation of the models, the contribution of the PPS to the study of retirement can be inferred from a comparison of the predictions of the different models.

The long-term forecasts of the solvency of the Social Security system suggest that there will be future reductions in the value of benefits. According to Trustees Report (1995), benefit cuts of approximately 20 percent would restore the solvency of the program when the trust fund is exhausted. To simulate the effects of such a reform, I assume a 20 percent decrease in the Social Security PIA (for all earnings levels) from its level in 1983 and calculate the new predicted probability of retirement for each observation. These new probabilities yield a new cumulative distribution function for the probability of being retired by each age. For a decrease in benefit levels of this magnitude, both the option value model and the retirement wealth accrual model predict a reduction in the probability of being retired by age 70 of about 1 percentage point. The explanation for the small magnitude of this effect is that it is the accrual of retirement wealth rather than its level that is the significant predictor of retirement. A uniform reduction in the generosity of Social 
Security benefits does not alter the relevant incentives by enough to generate substantially different retirement behavior.

Another policy change that can at least partially restore solvency to the program is to increase the normal retirement age. The second simulation immediately changes the normal retirement age for Social Security receipt from 65 to 67. As in the 1983 legislation that phased in this increase over several decades, the increase in the normal retirement age also increases the reduction for taking retirement benefits early at age 62 and decreases the delayed retirement credits for postponing retirement to age 70 . Applying the same methodology as in the benefit level simulation, both models that incorporate pension wealth data again predict a decrease in the cumulative probability of retirement between 50 and 70 of about 1 percentage point. ${ }^{27}$

It is also possible to reassess the importance of pensions suggested by the analysis of Stock and Wise (1990b) in light of the more representative sample of employees with pensions. One systematic change to pension incentives would be that employers were mandated to provide a pension to all employees. In the current sample, that corresponds to approximately a 50 percent increase in coverage. For the purposes of the simulation, the actual pension formula introduced corresponds to that graphed in Figure 1 above. The pension entitlements under this plan for all employees without pensions were calculated and used to simulate new retirement rates.

Extending coverage in the form of this defined benefit plan leads to a 4.9 percentage point increase in the probability of retiring between ages 50 and 70. Beller and Lawrence (1992) report that the growth of pension coverage between 1955 and 1975 (or 1950 and 1970) was also about 50 percent. Luzadis and Mitchell (1991) provide evidence that the growth in pensions during this

\footnotetext{
${ }^{27}$ When interpreting both of these simulations, it must be acknowledged that the imputation of Social Security benefits had many sources of imprecision. It is possible that if better wage histories were available, the Social Security wealth accrual would account for a greater share of the variation in the retirement wealth accrual and thereby generate larger predicted effects of these hypothetical policy reforms.
} 
period was disproportionately in those which provided retirement incentives similar to those in Figure 1. Special Committee on Aging (1991) documents a reduction in the labor force participation of men over 65 from 39.6 percent to 21.6 percent or 18 percentage points. Thus, growth in pension coverage can account for approximately 27 percent of the relevant decline in labor force participation rates.

When pension wealth data are not used in the estimates, the predicted increase in the probability of retirement is only 1.5 percentage points, based on the indicator variable for pension coverage in the third column of Table 4. Failing to account for pension incentives drastically underestimates the effect of pensions on retirement. However, when only the retirement wealth accrual is used instead of the option value model, the predicted change in the probability of retirement is 7.3 percentage points. The reason this estimate is about 50 percent higher than the one using the calculated option value is that it fails to account for the possibility of receiving the second large pension accrual (for early receipt of normal retirement benefits) after the early retirement age. Anyone with a sufficiently large pension accrual at the early retirement date takes advantage of it when only one year of accruals is considered. Under the option value model, some employees find it better to continue working and receive the second large accrual as well.

\section{Conclusion}

This paper has documented the importance of formally modeling pension incentives for retirement in a cross-section of the population. Both the option value of retirement and the accrual in retirement wealth are statistically significant in reducing the probability of retirement. There are two results of the analysis that are particularly important in considering the effects of pensions and Social Security on retirement. First, it is the change in retirement wealth, rather than its level, that 
affects the decision to retire. Second, it is pensions, not Social Security, that primarily determine the change in retirement wealth. As a result, changes in Social Security that are typical of past and proposed legislation are simulated to have modest impacts on labor force participation of about 1 percentage point. It is worth reiterating that the small effects found in Section VI may well be the consequence of the imprecision in the imputed wage histories that are critical determinants of Social Security benefits.

There is better evidence that the growth in pension coverage during the early postwar period contributed to the decline in labor force participation. Increasing coverage by approximately 50 percent generates a reduction in labor force participation of about 5 percentage points. This reduction is roughly 27 percent of the actual reduction that occurred during the period when pension coverage was extended by this amount.

By comparing the estimates and simulations from different specifications of the retirement models, the contribution of detailed pension datasets such as the PPS can be assessed. In this study, omitting pension information entirely leads to the erroneous conclusion that retirement wealth accruals and pension coverage have insignificant effects on the probability of retirement. Including even the one-year accrual in pension wealth reverses this conclusion and generates an important effect of pension incentives on retirement. For studying pension incentives, however, the one-year accrual of retirement wealth is insufficient. Simulations based on only the most immediate accrual tend to overstate the effect of pension coverage on retirement. In order to properly account for the tradeoff between retirement leisure and financial incentives to stay at a given firm, the retirement wealth accrual through the most advantageous year to retire--which is not necessarily the next year-must be incorporated. The version of the option value model of Stock and Wise (1990a) implemented here is able to accomplish this. 
The use of a unique dataset allows the results in two existing strands of the literature on retirement to be tied together. Many past studies have found small effects of Social Security on the probability of retirement in a cross-section of workers. There is nothing in the results presented here to suggest that those findings were misleading because the data used did not include comprehensive information on pension wealth accruals. More recent studies of pensions on the timing of retirement have found substantial effects of the details of pension formulas on retirement. The use of a more representative sample can qualify those initial results. The failure to model demographic variables explicitly had no substantive effect on the estimates. Focusing on only workers who had pensions slightly overstated the effect of pensions on job turnover, while the effect of pensions on departures from the labor force was somewhat larger than the effect of departures from the firm. 


\section{References}

Allen, Steven G., Robert L. Clark, and Ann A. McDermed (1992). "Post-Retirement Benefit Increases in the 1980s," in John A. Turner and Daniel J. Beller (eds.) Trends in Pensions 1992. Washington, DC: United States Department of Labor.

Atkinson, Anthony B. (1987). "Income Maintenance and Social Insurance," in Alan J. Auerbach and Martin S. Feldstein (eds.) Handbook of Public Economics, Vol. 2. New York: North Holland.

Avery, Robert B., Gregory E. Elliehausen, Glenn B. Canner, and Thomas Gustafson (1984a). "Survey of Consumer Finances, 1983," Federal Reserve Bulletin, Vol. 70, 679-692.

Avery, Robert B., Gregory E. Elliehausen, Glenn B. Canner, and Thomas Gustafson (1984b). "Survey of Consumer Finances, 1983: A Second Look," Federal Reserve Bulletin, Vol. 70, 857868.

Avery, Robert B., Gregory E. Elliehausen, and Arthur B. Kennickell (1987). "Changes in Consumer Installment Debt: Evidence from the 1983 and 1986 Surveys of Consumer Finances," Federal Reserve Bulletin, Vol. 73, 761-778.

Beller, Daniel J. and Helen H. Lawrence (1992). "Trends in Private Pension Plan Coverage," in John A. Turner and Daniel J. Beller (eds.) Trends in Pensions 1992. Washington, DC: United States Department of Labor.

Berkovec, James and Steven Stern (1991). "Job Exit Behavior of Older Men." Econometrica 59, $189-210$.

Bloom, David E. and Richard B. Freeman (1992). "The Fall in Private Pension Coverage in the United States," American Economic Review. Vol. 82, No. 2, 539-545.

Board of Governors of the Federal Reserve System (1990). Balance Sheets for the U.S. Economy, 1945-89. Washington, DC.

Board of Trustees, Federal Old-Age Survivors Insurance and Disability Trust Funds. Annual Report. Washington: U.S. Government Printing Office, 1995. [cited as Trustees Report (1995)]

Bureau of Labor Statistics (1997). Employment and Earnings. Washington, DC: Department of Labor, January.

Burtless, Gary (1986). "Social Security, Unanticipated Benefit Increases, and the Timing of Retirement," Review of Economic Studies, Vol. 53, 781-805.

Burtless, Gary and Robert A. Moffitt (1984). "The Effect of Social Security Benefits on the Labor Supply of the Aged," in Henry J. Aaron and Gary Burtless (eds.) Retirement and Economic Behavior. Washington, DC: The Brookings Institution. 
Chen, Yung-Ping (1992). "The Role of Private Pensions in the Income of Older Americans," in John A. Turner and Daniel J. Beller (eds.) Trends in Pensions 1992. Washington, DC: United States Department of Labor.

Costa, Dora L. (1997). The Evolution of Retirement: An American History, 1890-1990. Chicago: University of Chicago Press.

Diamond, Peter and Jonathan Gruber (1997). "Social Security and Retirement in the U.S." National Bureau of Economic Research, Working Paper No. 6097, July.

Diamond, Peter A. and Jerry A. Hausman (1984). "The Retirement and Unemployment Behavior of Older Men," in Henry J. Aaron and Gary Burtless (eds.) Retirement and Economic Behavior. Washington, DC: The Brookings Institution.

Faber, Joseph (1982). Life Tables for the United States, 1900-2050. Washington, DC: Social Security Administration.

Gruber, Jonathan and David A. Wise (1997). "Social Security Programs and Retirement Around the World," National Bureau of Economic Research, Working Paper No. 6134, August.

Gustman, Alan L. and Thomas L. Steinmeier (1986). "A Structural Retirement Model." Econometrica 54, 555-584.

Gustman, Alan L., Olivia S. Mitchell, Andrew A. Samwick, and Thomas L. Steinmeier (1997). "Pension and Social Security Wealth in the Health and Retirement Study," National Bureau of Economic Research, Working Paper No. 5912, February.

Hausman, Jerry A. and David A. Wise (1985). "Social Security, Health Status, and Retirement," in David A. Wise (ed.) Pensions, Labor, and Individual Choice. Chicago: University of Chicago Press.

Kotlikoff, Laurence J. and David A. Wise (1987). "The Incentive Effects of Private Pension Plans," in Zvi Bodie, John B. Shoven, and David A. Wise (eds.) Issues in Pension Economics. Chicago: University of Chicago Press.

Kotlikoff, Laurence J. and David A. Wise (1989). "Employee Retirement and a Firm's Pension Plan," in David A. Wise (ed.) The Economics of Aging. Chicago: University of Chicago Press.

Lumsdaine, Robin L., James H. Stock, and David A. Wise (1992). "Three Models of Retirement: Computational Complexity Versus Predictive Validity," in David A. Wise (ed.) Topics in the Economics of Aging. Chicago: University of Chicago Press.

Lumsdaine, Robin L. and David A. Wise (1990). "Aging and Labor Force Participation: A Review of Trends and Explanations," National Bureau of Economic Research Working Paper No. 3240. 
Luzadis, Rebecca A. and Olivia S. Mitchell (1991). "Explaining Pension Dynamics," Journal of Human Resources, Vol. 26, No. 4, 679-703.

Madrian, Brigitte C. (1993). "Post-Retirement Health Insurance and the Decision to Retire," Manuscript, Massachusetts Institute of Technology.

Mitchell, Olivia S. (1992). "Trends in Pension Benefit Formulas and Retirement Provisions," in John A. Turner and Daniel J. Beller (eds.) Trends in Pensions 1992. Washington, DC: United States Department of Labor.

Quinn, Joseph, Richard Burkhauser, and Daniel Myers (1990). Passing the Torch: The Influence of Economic Incentives on Work and Retirement. Kalamazoo, MI: W.E. Upjohn Institute for Employment Research.

Ransom, Roger L. and Richard Sutch (1988). "The Decline of Retirement and the Rise of Efficiency Wages: U.S. Retirement Patterns, 1870-1940," in R. Ricardo-Campbell and E. Lazear (eds.) Issues in Contemporary Retirement. Stanford, CA: Hoover Institution, 3-37.

Reno, Virginia P. (1993). "The Role of Pensions in Retirement Income," in Richard V. Burkhauser and Dallas L. Salisbury (eds.) Pensions in a Changing Economy. Washington, DC: Employee Benefit Research Institute.

Rogers, W. H. (1993). "Regression Standard Errors in Clustered Samples," Stata Technical Bulletin. Vol. 13, 19-23.

Ruhm, Christopher J. (1990). "Bridge Jobs and Partial Retirement," Journal of Labor Economics. Vol. 8, 482-501.

Rust, John (1989). "A Dynamic Programming Model of Retirement Behavior," in David A. Wise (ed.) The Economics of Aging. Chicago: University of Chicago Press.

Samwick, Andrew A. (1993). "Retirement Incentives in the 1983 Pension Provider Survey," Manuscript, Massachusetts Institute of Technology.

Silverman, Celia, Carolyn Pemberton, and Debora Holmes (1995). EBRI Databook on Employee Benefits, Third Edition. Washington, DC: Employee Benefits Research Institute

Social Security Administration (1994). Income of the Population 55 or Older. Washington, DC: Department of Health and Human Services.

Social Security Administration (1995). Social Security Bulletin Annual Statistical Supplement. Washington, DC: Department of Health and Human Services.

Special Committee on Aging (1991). Aging America: Trends and Projections. Washington, DC: United States Senate. 
Steinberg, Richard M. and Harold Dankner (1987). Pensions: A Financial Reporting and Compliance Guide. New York: John Wiley \& Sons, Inc.

Stock, James H. and David A. Wise (1990a). "Pensions, the Option Value of Work, and Retirement," Econometrica, Vol. 58, No. 5, 1151-1180.

Stock, James H. and David A. Wise (1990b). "The Pension Inducement to Retire: An Option Value Analysis," in David A. Wise (ed.) Issues in the Economics of Aging. Chicago: University of Chicago Press.

Sueyoshi, Glenn T. (1989). "Social Security and the Determinants of Full and Partial Retirement: A Competing Risks Analysis," National Bureau of Economic Research Working Paper No. 3113.

Woodbury, Richard (1997). "The Motivations for Business Retirement Policies," Manuscript, National Bureau of Economic Research, May. 
Figure 1

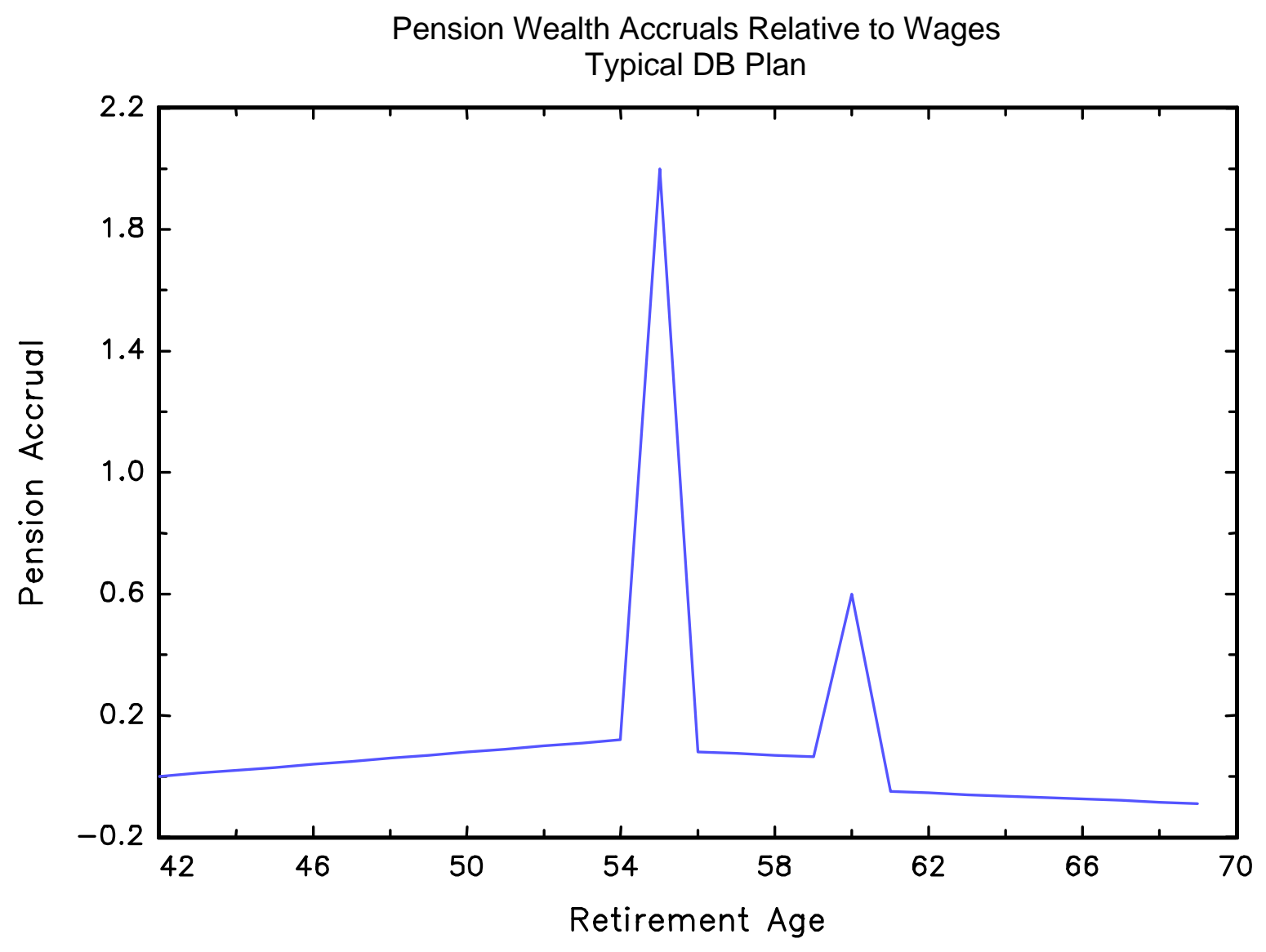


Figure 2

Pension Accruals Relative to Wages

Weighted Average of All Plans: Hired at 31, Average Wage

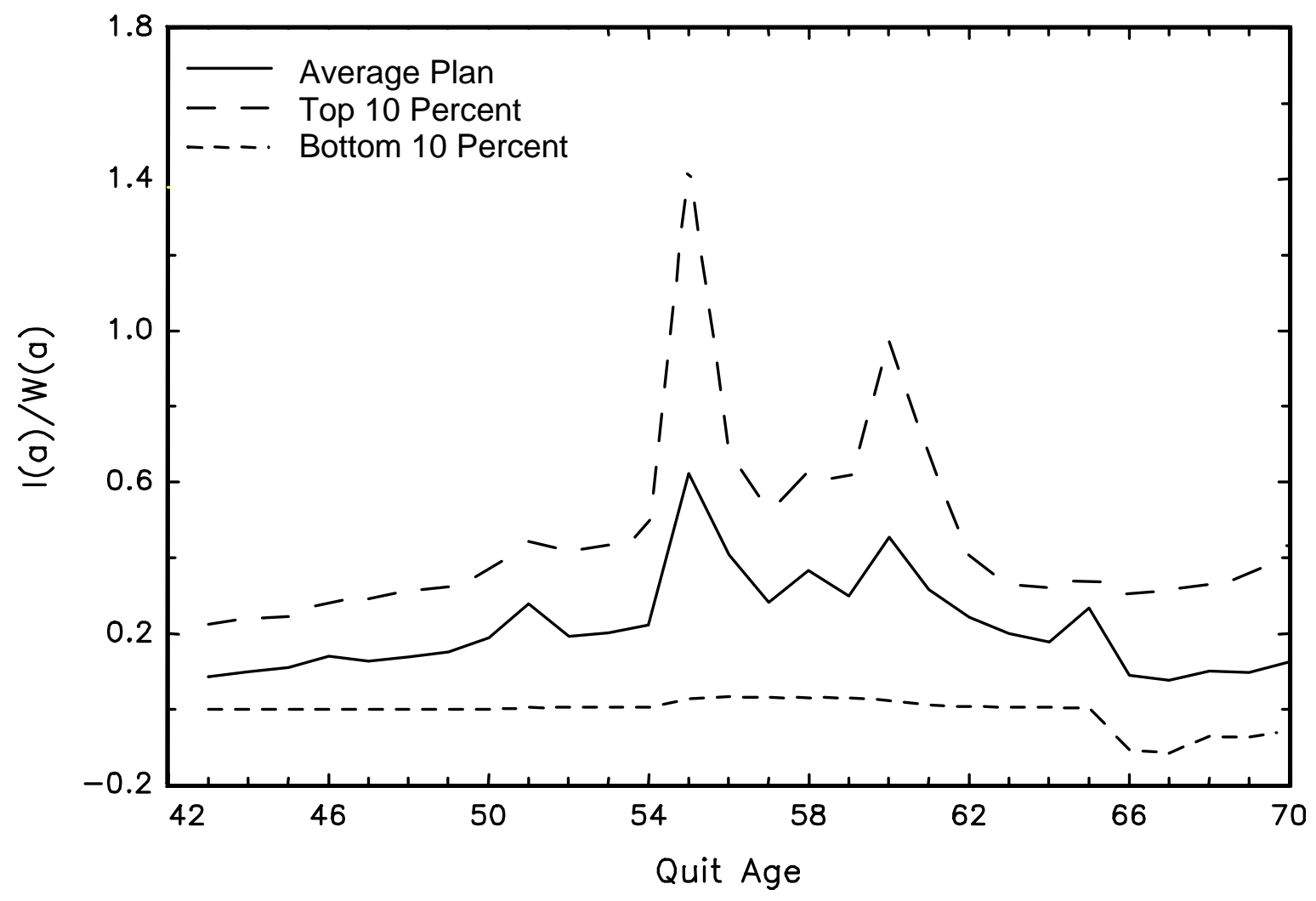


Figure 3

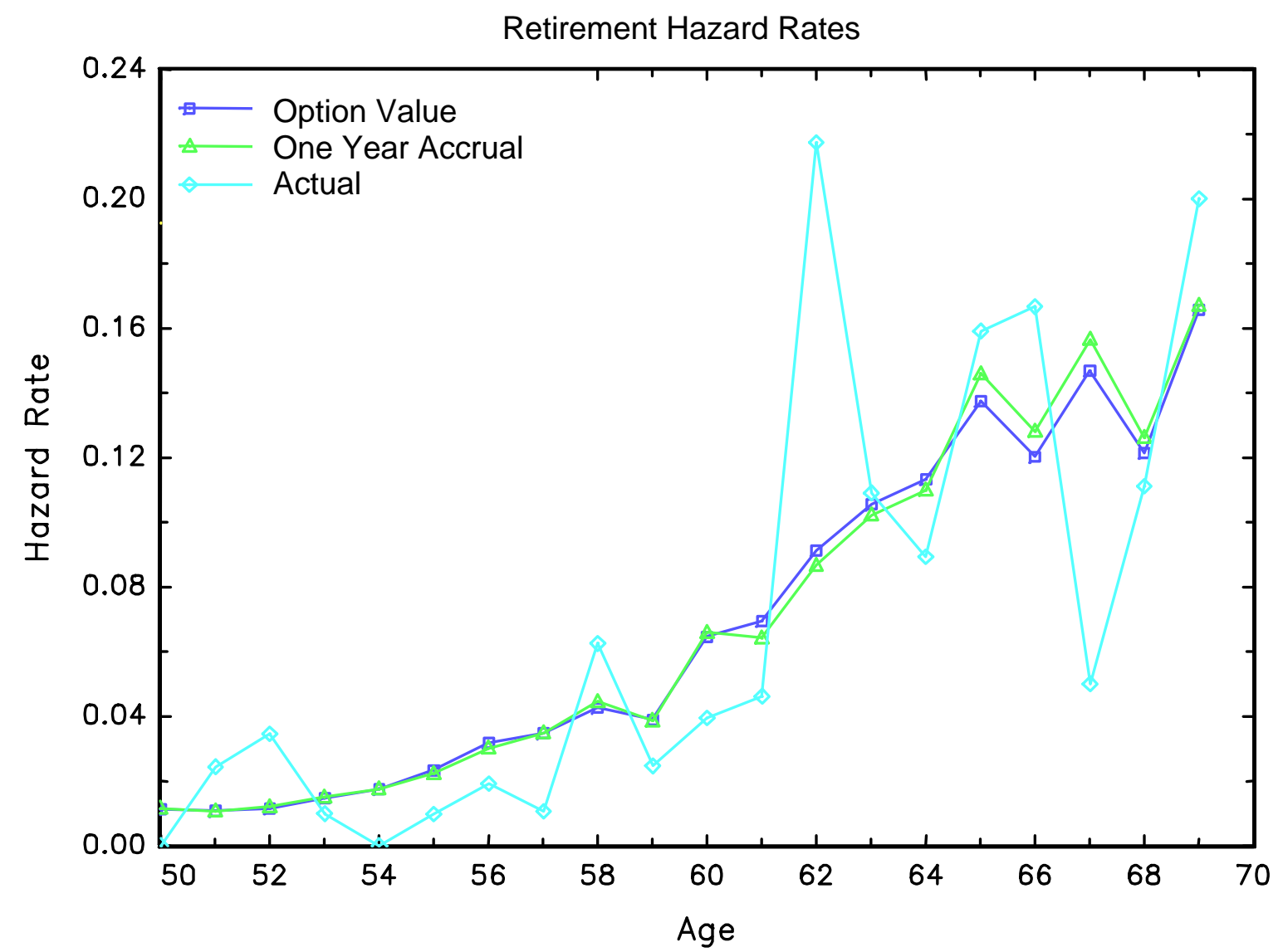


Table 1

\begin{tabular}{|c|c|c|c|c|}
\hline \multicolumn{5}{|c|}{ Summary Statistics for Explanatory Variables in SCF, with comparisons to HRS } \\
\hline \multirow[b]{2}{*}{ Variable } & \multicolumn{2}{|c|}{ Survey of Consumer Finances ${ }^{\mathrm{a}}$} & \multicolumn{2}{|c|}{ Health and Retirement Survey ${ }^{\mathrm{b}}$} \\
\hline & Mean & Std. Deviation & Mean & Std.Deviation \\
\hline Earnings (1983 \$) & 22,028 & 25,571 & 17,724 & 171,492 \\
\hline Pension Coverage & 0.654 & 0.476 & 0.698 & 0.459 \\
\hline Age & 56.566 & 4.685 & 55.583 & 3.123 \\
\hline Education (years) & 12.583 & 3.080 & 12.740 & 2.845 \\
\hline Non-white & 0.118 & 0.323 & 0.176 & 0.381 \\
\hline Poor health & 0.011 & 0.106 & 0.020 & 0.139 \\
\hline Female & 0.468 & 0.499 & 0.462 & 0.499 \\
\hline Married & 0.760 & 0.427 & 0.744 & 0.436 \\
\hline Tenure (years) & 15.035 & 10.992 & 12.929 & 10.956 \\
\hline Number of Observations & & & & \\
\hline \multicolumn{5}{|c|}{$\begin{array}{l}\text { a) Author's calculations from SCF } 1983 \text {. Relevant sample is all fulltime workers (excluding } \\
\text { military and self-employed) ages } 50 \text { to } 69 \text { in } 1983 \text { who are re-interviewed in SCF } 1986 \text { and not } \\
\text { omitted from the PPS if they report being covered by a pension in the SCF. Data are weighted using } \\
\text { extended income weights.. }\end{array}$} \\
\hline \multicolumn{5}{|c|}{$\begin{array}{l}\text { b) Author's calculations from the HRS, Wave } 1 . \text { The sample is comprised of all age-eligible (50 to } 62 \\
\text { in 1992), fulltime workers (excluding military and self-employed). Data are weighted using person- } \\
\text { level weights. }\end{array}$} \\
\hline
\end{tabular}


Table 2

\begin{tabular}{|c|c|c|c|c|c|c|}
\hline \multicolumn{7}{|c|}{ Pension and Social Security Wealth and Accruals in 1983} \\
\hline & \multicolumn{3}{|c|}{ Levels } & \multicolumn{3}{|c|}{ Ratio to Wages } \\
\hline & Mean & Median & $\begin{array}{l}\text { Standard } \\
\text { Deviation }\end{array}$ & Mean & Median & $\begin{array}{r}\text { Standard } \\
\text { Deviation }\end{array}$ \\
\hline \multicolumn{7}{|l|}{ Full Sample } \\
\hline Social Security Wealth & 47,018 & 46,437 & 25,551 & 3.243 & 2.577 & 4.110 \\
\hline Social Security Accrual & -805 & -544 & 2,111 & -0.071 & -0.026 & 0.246 \\
\hline Pension Wealth & 29,710 & 0 & 63,330 & 1.138 & 0 & 1.812 \\
\hline Pension Accrual & 956 & 0 & 9,767 & 0.042 & 0 & 0.299 \\
\hline Earnings & 22,028 & 17,440 & 25,571 & & & \\
\hline Financial Assets & 58,132 & 8,986 & 355,771 & & & \\
\hline Housing Net Equity & 58,931 & 46,506 & 95,136 & & & \\
\hline \multicolumn{7}{|l|}{$\begin{array}{l}\text { Eligible for both Social } \\
\text { Security and Pensions }\end{array}$} \\
\hline Social Security Wealth & 52,535 & 51,134 & 23,616 & 2.835 & 2.582 & 1.715 \\
\hline Social Security Accrual & -851 & -703 & 2,110 & -0.048 & -0.035 & 0.128 \\
\hline Pension Wealth & 39,152 & 17,877 & 65,823 & 1.526 & 0.947 & 1.761 \\
\hline Pension Accrual & 1,873 & 55 & 11,830 & 0.075 & 0.003 & 0.359 \\
\hline Earnings & 23,707 & 19,378 & 26,098 & & & \\
\hline Financial Assets & 62,038 & 11,045 & 416,629 & & & \\
\hline Housing Net Equity & 55,755 & 47,475 & 86,661 & & & \\
\hline \multicolumn{7}{|c|}{$\begin{array}{l}\text { Notes: } \\
\text { a) Author's calculations using SCF and PPS. } \\
\text { b) Sample size is } 525 \text { for full sample, } 305 \text { for sample restricted by eligibility. } \\
\text { c) See text for explanation of variables. }\end{array}$} \\
\hline
\end{tabular}


Table 3

\begin{tabular}{|c|c|c|c|}
\hline \multicolumn{4}{|c|}{ Retirement Probits -- Dependent Variable Includes All Job Changes } \\
\hline Variable & Option Value & $\begin{array}{l}\text { Retirement Wealth } \\
\text { Includes Pension }\end{array}$ & $\begin{array}{l}\text { Retirement Wealth } \\
\text { Excludes Pension }\end{array}$ \\
\hline $\begin{array}{l}\text { Option Value of } \\
\text { Retirement }\end{array}$ & $\begin{array}{l}-0.1562 \\
(0.0512)\end{array}$ & ----- & ----- \\
\hline Retirement Wealth & $\begin{array}{c}0.0011 \\
(0.0005)\end{array}$ & $\begin{array}{c}0.0002 \\
(0.0008)\end{array}$ & $\begin{array}{l}-0.0007 \\
(0.0027)\end{array}$ \\
\hline $\begin{array}{l}\text { Retirement Wealth } \\
\text { Accrual }\end{array}$ & ----- & $\begin{array}{l}-0.0215 \\
(0.0066)\end{array}$ & $\begin{array}{l}-0.0204 \\
(0.0220)\end{array}$ \\
\hline Pension Coverage & ----- & ----- & $\begin{array}{l}-0.0963 \\
(0.0966)\end{array}$ \\
\hline Wage & $\begin{array}{c}0.0034 \\
(0.0019)\end{array}$ & $\begin{array}{l}-0.0019 \\
(0.0013)\end{array}$ & $\begin{array}{l}-0.0008 \\
(0.0008)\end{array}$ \\
\hline Age & $\begin{array}{c}0.0232 \\
(0.0113)\end{array}$ & $\begin{array}{c}0.0297 \\
(0.0107)\end{array}$ & $\begin{array}{c}0.0397 \\
(0.0120)\end{array}$ \\
\hline Education & $\begin{array}{l}-0.0023 \\
(0.0155)\end{array}$ & $\begin{array}{l}-0.0122 \\
(0.0153)\end{array}$ & $\begin{array}{l}-0.0153 \\
(0.0150)\end{array}$ \\
\hline Nonwhite & $\begin{array}{l}-0.1265 \\
(0.1597)\end{array}$ & $\begin{array}{l}-0.1293 \\
(0.1605)\end{array}$ & $\begin{array}{l}-0.1421 \\
(0.1620)\end{array}$ \\
\hline Poor Health & $\begin{array}{c}0.2759 \\
(0.2895)\end{array}$ & $\begin{array}{c}0.2907 \\
(0.2882)\end{array}$ & $\begin{array}{c}0.2889 \\
(0.2936)\end{array}$ \\
\hline Female & $\begin{array}{l}-0.0002 \\
(0.1090)\end{array}$ & $\begin{array}{c}0.0508 \\
(0.1073)\end{array}$ & $\begin{array}{c}0.0565 \\
(0.1061)\end{array}$ \\
\hline Married & $\begin{array}{l}-0.0940 \\
(0.1257)\end{array}$ & $\begin{array}{l}-0.0618 \\
(0.1251)\end{array}$ & $\begin{array}{l}-0.0893 \\
(0.1216)\end{array}$ \\
\hline Tenure & $\begin{array}{l}-0.0087 \\
(0.0047)\end{array}$ & $\begin{array}{l}-0.0088 \\
(0.0048)\end{array}$ & $\begin{array}{l}-0.0038 \\
(0.0046)\end{array}$ \\
\hline Financial Assets & $\begin{array}{c}0.00001 \\
(0.00003)\end{array}$ & $\begin{array}{c}0.00001 \\
(0.00003)\end{array}$ & $\begin{array}{c}0.00003 \\
(0.00003)\end{array}$ \\
\hline Housing Net Equity & $\begin{array}{l}-0.0014 \\
(0.0006)\end{array}$ & $\begin{array}{l}-0.0019 \\
(0.0007)\end{array}$ & $\begin{array}{l}-0.0016 \\
(0.0007)\end{array}$ \\
\hline Constant & $\begin{array}{c}-1.9076 \\
(0.7120)\end{array}$ & $\begin{array}{c}-2.3358 \\
(0.6658)\end{array}$ & $\begin{array}{l}-2.8712 \\
(0.7179)\end{array}$ \\
\hline Log-Likelihood & 452.224 & 454.026 & 465.387 \\
\hline \multicolumn{4}{|c|}{$\begin{array}{l}\text { Notes: } \\
\text { a) Author's calculations using SCF and PPS. } \\
\text { b) The dependent variable is } 1 \text { if employee leaves job held in 1983, } 0 \text { otherwise } \\
\text { c) The retirement wealth and accruals include both Social Security and pensions in column } 2 \text { but only Social } \\
\text { Security in column } 3 \text {. } \\
\text { d) Number of Employees: } 520 \text { Number of Observations: } 1389 \\
\text { e) All dollar amounts are in thousands. All specifications include indicator variables for year (2). } \\
\text { f) The reported standard errors in parentheses are adjusted for heteroskedasticity and clustering within households. }\end{array}$} \\
\hline
\end{tabular}


Table 4

\begin{tabular}{|c|c|c|c|}
\hline \multicolumn{4}{|c|}{ Retirement Probits -- Dependent Variable Includes Only Departures from Labor Force } \\
\hline Variable & Option Value & $\begin{array}{l}\text { Retirement Wealth } \\
\text { Includes Pension }\end{array}$ & $\begin{array}{l}\text { Retirement Wealth } \\
\text { Excludes Pension }\end{array}$ \\
\hline $\begin{array}{l}\text { Option Value of } \\
\text { Retirement }\end{array}$ & $\begin{array}{l}-0.1466 \\
(0.1025)\end{array}$ & ----- & ----- \\
\hline Retirement Wealth & $\begin{array}{c}0.0010 \\
(0.0008)\end{array}$ & $\begin{array}{l}0.00001 \\
(0.0012)\end{array}$ & $\begin{array}{l}-0.0026 \\
(0.0035)\end{array}$ \\
\hline $\begin{array}{l}\text { Retirement Wealth } \\
\text { Accrual }\end{array}$ & ----- & $\begin{array}{l}-0.0236 \\
(0.0089)\end{array}$ & $\begin{array}{l}-0.0350 \\
(0.0266)\end{array}$ \\
\hline Pension Coverage & ----- & ----- & $\begin{array}{c}0.0566 \\
(0.1413)\end{array}$ \\
\hline Wage & $\begin{array}{c}0.0006 \\
(0.0037)\end{array}$ & $\begin{array}{l}-0.0054 \\
(0.0018)\end{array}$ & $\begin{array}{l}-0.0026 \\
(0.0019)\end{array}$ \\
\hline Age & $\begin{array}{c}0.0755 \\
(0.0159)\end{array}$ & $\begin{array}{c}0.0804 \\
(0.0150)\end{array}$ & $\begin{array}{c}0.0879 \\
(0.0170)\end{array}$ \\
\hline Education & $\begin{array}{l}-0.0019 \\
(0.0213)\end{array}$ & $\begin{array}{l}-0.0065 \\
(0.0204)\end{array}$ & $\begin{array}{l}-0.0130 \\
(0.0202)\end{array}$ \\
\hline Nonwhite & $\begin{array}{l}-0.0522 \\
(0.1907)\end{array}$ & $\begin{array}{l}-0.0550 \\
(0.1902)\end{array}$ & $\begin{array}{l}-0.0813 \\
(0.1924)\end{array}$ \\
\hline Poor Health & $\begin{array}{c}0.2440 \\
(0.5653)\end{array}$ & $\begin{array}{c}0.2456 \\
(0.5498)\end{array}$ & $\begin{array}{c}0.3066 \\
(0.5694)\end{array}$ \\
\hline Female & $\begin{array}{c}0.2155 \\
(0.1451)\end{array}$ & $\begin{array}{c}0.2342 \\
(0.1443)\end{array}$ & $\begin{array}{c}0.2351 \\
(0.1429)\end{array}$ \\
\hline Married & $\begin{array}{l}-0.0673 \\
(0.1607)\end{array}$ & $\begin{array}{l}-0.0611 \\
(0.1609)\end{array}$ & $\begin{array}{l}-0.0914 \\
(0.1532)\end{array}$ \\
\hline Tenure & $\begin{array}{c}0.0057 \\
(0.0059)\end{array}$ & $\begin{array}{c}0.0053 \\
(0.0061)\end{array}$ & $\begin{array}{c}0.0093 \\
(0.0058)\end{array}$ \\
\hline Financial Assets & $\begin{array}{c}0.00002 \\
(0.00004)\end{array}$ & $\begin{array}{c}0.00002 \\
(0.00004)\end{array}$ & $\begin{array}{c}0.00003 \\
(0.00004)\end{array}$ \\
\hline Housing Net Equity & $\begin{array}{l}-0.0012 \\
(0.0006)\end{array}$ & $\begin{array}{l}-0.0016 \\
(0.0008)\end{array}$ & $\begin{array}{l}-0.0013 \\
(0.0008)\end{array}$ \\
\hline Constant & $\begin{array}{c}-5.7794 \\
(0.9987)\end{array}$ & $\begin{array}{l}-6.0910 \\
(0.8883)\end{array}$ & $\begin{array}{l}-6.4930 \\
(1.0092)\end{array}$ \\
\hline Log-Likelihood & 234.316 & 234.030 & 239.266 \\
\hline \multicolumn{4}{|c|}{$\begin{array}{l}\text { Notes: } \\
\text { a) Author's calculations using SCF and PPS. } \\
\text { b) The dependent variable is } 1 \text { if employee retires from the labor force, } 0 \text { otherwise } \\
\text { c) The retirement wealth and accruals include both Social Security and pensions in column } 2 \text { but only Social } \\
\text { Security in column } 3 \text {. }\end{array}$} \\
\hline
\end{tabular}


Table 5

\begin{tabular}{|c|c|c|c|c|}
\hline \multicolumn{5}{|c|}{ Retirement Probits -- Employees With Both Social Security and Pensions } \\
\hline \multirow[b]{2}{*}{ Variable } & \multicolumn{2}{|c|}{ All Job Changes } & \multicolumn{2}{|c|}{ Departures from the Labor Force } \\
\hline & Option Value & $\begin{array}{l}\text { Retirement Wealth } \\
\text { Includes Pension }\end{array}$ & Option Value & $\begin{array}{l}\text { Retirement Wealth } \\
\text { Includes Pension }\end{array}$ \\
\hline $\begin{array}{l}\text { Option Value of } \\
\text { Retirement }\end{array}$ & $\begin{array}{l}-0.2077 \\
(0.0769)\end{array}$ & ----- & $\begin{array}{l}-0.4519 \\
(0.1489)\end{array}$ & ----- \\
\hline Retirement Wealth & $\begin{array}{l}-0.0008 \\
(0.0008)\end{array}$ & $\begin{array}{l}-0.0014 \\
(0.0009)\end{array}$ & $\begin{array}{l}-0.0021 \\
(0.0017)\end{array}$ & $\begin{array}{l}-0.0019 \\
(0.0020)\end{array}$ \\
\hline $\begin{array}{l}\text { Retirement Wealth } \\
\text { Accrual }\end{array}$ & ----- & $\begin{array}{l}-0.0216 \\
(0.0071)\end{array}$ & ----- & $\begin{array}{l}-0.0281 \\
(0.0120)\end{array}$ \\
\hline Pension Coverage & ----- & ----- & ----- & ----- \\
\hline Wage & $\begin{array}{c}0.0072 \\
(0.0030)\end{array}$ & $\begin{array}{l}-0.0002 \\
(0.0011)\end{array}$ & $\begin{array}{c}0.0143 \\
(0.0064)\end{array}$ & $\begin{array}{l}-0.0032 \\
(0.0024)\end{array}$ \\
\hline Age & $\begin{array}{c}0.0561 \\
(0.0167)\end{array}$ & $\begin{array}{c}0.0689 \\
(0.0156)\end{array}$ & $\begin{array}{c}0.1038 \\
(0.0232)\end{array}$ & $\begin{array}{c}0.1333 \\
(0.0234)\end{array}$ \\
\hline Education & $\begin{array}{c}0.0182 \\
(0.0229)\end{array}$ & $\begin{array}{c}0.0020 \\
(0.0222)\end{array}$ & $\begin{array}{c}0.0361 \\
(0.0338)\end{array}$ & $\begin{array}{c}0.0126 \\
(0.0307)\end{array}$ \\
\hline Nonwhite & $\begin{array}{l}-0.3385 \\
(0.2218)\end{array}$ & $\begin{array}{l}-0.3266 \\
(0.2186)\end{array}$ & $\begin{array}{l}-0.4928 \\
(0.2946)\end{array}$ & $\begin{array}{l}-0.4726 \\
(0.2865)\end{array}$ \\
\hline Poor Health & $\begin{array}{c}0.6393 \\
(0.1757)\end{array}$ & $\begin{array}{c}0.6966 \\
(0.1739)\end{array}$ & ----- & ----- \\
\hline Female & $\begin{array}{l}-0.0873 \\
(0.1504)\end{array}$ & $\begin{array}{l}-0.0104 \\
(0.1525)\end{array}$ & $\begin{array}{l}-0.0500 \\
(0.2247)\end{array}$ & $\begin{array}{c}0.0041 \\
(0.2227)\end{array}$ \\
\hline Married & $\begin{array}{l}-0.2645 \\
(0.1617)\end{array}$ & $\begin{array}{l}-0.2089 \\
(0.1596)\end{array}$ & $\begin{array}{l}-0.1785 \\
(0.2181)\end{array}$ & $\begin{array}{l}-0.1644 \\
(0.2157)\end{array}$ \\
\hline Tenure & $\begin{array}{c}0.0084 \\
(0.0059)\end{array}$ & $\begin{array}{c}0.0103 \\
(0.0063)\end{array}$ & $\begin{array}{c}0.0122 \\
(0.0083)\end{array}$ & $\begin{array}{c}0.0148 \\
(0.0090)\end{array}$ \\
\hline Financial Assets & $\begin{array}{c}0.00002 \\
(0.00004)\end{array}$ & $\begin{array}{c}0.00003 \\
(0.00004)\end{array}$ & $\begin{array}{c}0.00008 \\
(0.00005)\end{array}$ & $\begin{array}{c}0.00008 \\
(0.00005)\end{array}$ \\
\hline Housing Net Equity & $\begin{array}{l}-0.0015 \\
(0.0007)\end{array}$ & $\begin{array}{l}-0.0020 \\
(0.0009)\end{array}$ & $\begin{array}{l}-0.0032 \\
(0.0014)\end{array}$ & $\begin{array}{l}-0.0036 \\
(0.0016)\end{array}$ \\
\hline Constant & $\begin{array}{c}-4.0264 \\
(1.0885)\end{array}$ & $\begin{array}{c}-4.8979 \\
(1.0030)\end{array}$ & $\begin{array}{l}-7.2245 \\
(1.5159)\end{array}$ & $\begin{array}{l}-9.2638 \\
(1.5008)\end{array}$ \\
\hline Log-Likelihood & 243.977 & 246.555 & 120.366 & 124.646 \\
\hline \multicolumn{5}{|c|}{$\begin{array}{l}\text { Notes: } \\
\text { a) Author's calculations using SCF and PPS. } \\
\text { b) Number of Employees: } 300 \text { Number of Observations: } 852 \\
\text { c) All dollar amounts are in thousands. All specifications include indicator variables for year (2). } \\
\text { d) The reported standard errors are adjusted for heteroskedasticity and clustering within households. }\end{array}$} \\
\hline
\end{tabular}




\section{Appendix A: Sample Attrition}

Approximately one fourth of the individuals in the 1983 wave of the SCF who were employed fulltime were not reinterviewed in the 1986 survey. To the extent that this attrition is nonrandom, there is the potential for the parameters of the estimated retirement models to be inconsistent. If any of the determinants of sample attrition also influence retirement behavior, then the coefficients will reflect not just the variable's impact on retirement but the variable's impact on the likelihood of being reinterviewed.

The appropriate econometric technique to correct for this bias is to model the retirement outcomes observed in the SCF panel jointly with the attrition process. To do so, let $\mathrm{y}_{1}{ }^{*}$ and $\mathrm{y}_{2}{ }^{*}$ denote the latent variable for retirement and sample attrition, respectively. The full model to be estimated is now a bivariate probit of the form:

$$
\begin{aligned}
& y_{l i t}^{*}=\beta_{I^{\prime}} X_{l i t}+\varepsilon_{l i t} \\
& y_{2 i}^{*}=\beta_{2^{\prime}} X_{2 i l}+\varepsilon_{2 i l} \\
& {\left[\begin{array}{l}
\varepsilon_{l i t} \\
\varepsilon_{2 i l}
\end{array}\right] \sim N(0, \Sigma)} \\
& \Sigma=\left[\begin{array}{cc}
\sigma_{1}^{2} & \rho \\
\rho & \sigma_{2}^{2}
\end{array}\right]
\end{aligned}
$$

where $\sigma_{1}{ }^{2}$ and $\sigma_{2}{ }^{2}$ are normalized to unity (as in the case of the univariate probit) and is the correlation between the disturbance terms in the two equations. Letting ${ }_{2}\left(\mathrm{z}_{1}, \mathrm{z}_{2}\right)$ denote the cumulative distribution function for a standard bivariate normal with correlation, the loglikelihood function for the full model is: 


$$
\begin{gathered}
L(X, y, \beta)=\sum_{i=1}^{N} \sum_{t=1}^{T_{i}}\left[y_{2 i} y_{l i t} \log \Phi_{2}\left(\beta_{I^{\prime}} X_{l i t}, \beta_{2^{\prime}} X_{2 i l}, \rho\right)+\right. \\
y_{2 i}\left(1-y_{1 i t}\right) \log \Phi_{2}\left(-\beta_{I^{\prime}} X_{1 i t}, \beta_{2^{\prime}} X_{2 i l}, \rho\right)+ \\
\left.\left(1-y_{2 i}\right) \log \Phi\left(-\beta_{2^{\prime}} X_{2 i l}\right)\right]
\end{gathered}
$$

where $\mathrm{i}$ indexes individuals and $\mathrm{t}$ indexes the years for which the individual is observed in the sample. Note that the assumption of independence across all observations is still maintained. The first term in the summation corresponds to the likelihood contribution of for an individual who is observed in the 1986 survey and retires in year t. The second term is the contribution of an individual who is observed in the 1986 survey and does not retire in year t. The third term is the contribution of an individual who is not observed in the 1986 survey and whose retirement status cannot therefore be determined.

The columns of $\mathrm{X}_{2}$ should include any variables that will predict sample attrition. The SCF 1983 includes several questions that are relevant for whether a household is likely to be located for an interview three years later. The most important economic variable is whether the individual owns a home; those who do are less likely to relocate and will therefore be easier to find. Residing in a central city (instead of the suburbs or outlying areas) may also predict locational change. Also important for predicting sample attrition are characteristics of the interview itself. Respondents who are suspicious of the interview process or who are reluctant to participate may also be more difficult to locate and interview in the second survey.

Table A1 presents full-information maximum likelihood estimates of the model in (A.2) in which the probit for retirement is the same as that in Table 4. The probit for being reinterviewed contains all the variables from the retirement model (except the indicators for year) plus those designed to predict attrition. Several aspects of this table are noteworthy. 
First, the two most significant variables that predict attrition (in the table, those below the dashed line) are whether the person owns a home or was found by the interviewer to be suspicious after the interview (the latter is a categorical variable which increases with the perceived level of suspicion). Attrition does not significantly depend on whether the respondent was perceived to show any interest in the process or used documents to answer the questions. Respondents who have never been married or who live in the central city of an SMSA are less likely to be reinterviewed, as are respondents who were suspicious at the beginning of the interview or who were among the last interviews to be processed by the survey sponsors.

Second, among the variables that also appear in the retirement probit, only tenure is a significant predictor of whether the person will be reinterviewed. Employees who had been working in the same job for more years were more likely to be reinterviewed in 1986. In particular, none of the retirement wealth, accrual, or option value variables are significant in the reinterview probit.

Third, the coefficients on the option value of retirement and the retirement wealth accrual are nearly identical in all three retirement probits (in the table, those above the dashed line) to their counterparts in Table 4. The change in the magnitude of the point estimates is -2.5 percent for the option value, -3.4 percent for the retirement wealth accrual, and 2.5 percent for the retirement wealth accrual excluding pensions. Both the option value and the accrual are also significant below the 5 percent significance level, as in Table 4. Because of the close correspondence between the retirement probits in Table 4 and those in Table A1, the analysis in the text will not formally model the nonrandom attrition between SCF surveys. 
Table A1

\begin{tabular}{|c|c|c|c|}
\hline \multicolumn{4}{|c|}{$\begin{array}{c}\text { Full Information Maximum Likelihood Retirement Probits } \\
\text { (Retirement Equation Above Dashed Line, Re-interview Equation Below Dashed Line) }\end{array}$} \\
\hline Variable & Option Value & $\begin{array}{l}\text { Retirement Wealth } \\
\text { Includes Pension }\end{array}$ & $\begin{array}{l}\text { Retirement Wealth } \\
\text { Excludes Pension }\end{array}$ \\
\hline $\begin{array}{l}\text { Option Value of } \\
\text { Retirement }\end{array}$ & $\begin{array}{l}-0.1431 \\
(0.0477)\end{array}$ & ----- & ----- \\
\hline Retirement Wealth & $\begin{array}{c}0.0010 \\
(0.0013)\end{array}$ & $\begin{array}{l}0.00008 \\
(0.0014)\end{array}$ & $\begin{array}{l}-0.0027 \\
(0.0035)\end{array}$ \\
\hline $\begin{array}{l}\text { Retirement Wealth } \\
\text { Accrual }\end{array}$ & ----- & $\begin{array}{l}-0.0228 \\
(0.0121)\end{array}$ & $\begin{array}{l}-0.0359 \\
(0.0298)\end{array}$ \\
\hline Pension Coverage & ----- & ----- & $\begin{array}{c}0.0620 \\
(0.1616)\end{array}$ \\
\hline Wage & $\begin{array}{c}0.0005 \\
(0.0040)\end{array}$ & $\begin{array}{l}-0.0048 \\
(0.0030)\end{array}$ & $\begin{array}{l}-0.0026 \\
(0.0012)\end{array}$ \\
\hline Age & $\begin{array}{c}0.0740 \\
(0.0164)\end{array}$ & $\begin{array}{c}0.0716 \\
(0.0177)\end{array}$ & $\begin{array}{c}0.0868 \\
(0.0189)\end{array}$ \\
\hline Education & $\begin{array}{l}-0.0011 \\
(0.0253)\end{array}$ & $\begin{array}{l}-0.0102 \\
(0.0241)\end{array}$ & $\begin{array}{l}-0.0114 \\
(0.0253)\end{array}$ \\
\hline Nonwhite & $\begin{array}{l}-0.1318 \\
(0.2541)\end{array}$ & $\begin{array}{c}0.0503 \\
(0.2479)\end{array}$ & $\begin{array}{l}-0.1532 \\
(0.2572)\end{array}$ \\
\hline Poor Health & $\begin{array}{c}0.2802 \\
(0.4853)\end{array}$ & $\begin{array}{c}0.1722 \\
(0.4996)\end{array}$ & $\begin{array}{c}0.3566 \\
(0.4901)\end{array}$ \\
\hline Female & $\begin{array}{c}0.2183 \\
(0.1646)\end{array}$ & $\begin{array}{c}0.2024 \\
(0.1602)\end{array}$ & $\begin{array}{c}0.2401 \\
(0.1693)\end{array}$ \\
\hline Married & $\begin{array}{l}-0.0835 \\
(0.1864)\end{array}$ & $\begin{array}{l}-0.0467 \\
(0.1817)\end{array}$ & $\begin{array}{l}-0.1023 \\
(0.1926)\end{array}$ \\
\hline Tenure & $\begin{array}{c}0.0069 \\
(0.0069)\end{array}$ & $\begin{array}{c}0.0016 \\
(0.0065)\end{array}$ & $\begin{array}{c}0.0102 \\
(0.0065)\end{array}$ \\
\hline Financial Assets & $\begin{array}{c}0.00002 \\
(0.00007)\end{array}$ & $\begin{array}{c}0.00002 \\
(0.00006)\end{array}$ & $\begin{array}{c}0.00003 \\
(0.00007)\end{array}$ \\
\hline Housing Net Equity & $\begin{array}{l}-0.0012 \\
(0.0014)\end{array}$ & $\begin{array}{l}-0.0015 \\
(0.0012)\end{array}$ & $\begin{array}{l}-0.0012 \\
(0.0013)\end{array}$ \\
\hline Constant & $\begin{array}{l}-5.7533 \\
(1.1340)\end{array}$ & $\begin{array}{l}-5.3174 \\
(1.2810)\end{array}$ & $\begin{array}{l}-6.5103 \\
(1.2280)\end{array}$ \\
\hline $\begin{array}{l}\text { Option Value of } \\
\text { Retirement }\end{array}$ & $\begin{array}{c}0.0195 \\
(0.0336)\end{array}$ & ----- & ----- \\
\hline Retirement Wealth & $\begin{array}{l}-0.0005 \\
(0.0004)\end{array}$ & $\begin{array}{l}-0.0005 \\
(0.0004)\end{array}$ & $\begin{array}{l}-0.0020 \\
(0.0026)\end{array}$ \\
\hline $\begin{array}{l}\text { Retirement Wealth } \\
\text { Accrual }\end{array}$ & ----- & $\begin{array}{c}0.0005 \\
(0.0050)\end{array}$ & $\begin{array}{l}-0.0243 \\
(0.0246)\end{array}$ \\
\hline
\end{tabular}




\begin{tabular}{|c|c|c|c|}
\hline \multicolumn{4}{|c|}{ Table A1, Parameters of Reinterview Equations, Continued } \\
\hline Variable & Option Value & $\begin{array}{l}\text { Retirement Wealth } \\
\text { Includes Pension }\end{array}$ & $\begin{array}{l}\text { Retirement Wealth } \\
\text { Excludes Pension }\end{array}$ \\
\hline Pension Coverage & ----- & ---- & $\begin{array}{c}0.0041 \\
(0.1092)\end{array}$ \\
\hline Wage & $\begin{array}{l}-0.0013 \\
(0.0014)\end{array}$ & $\begin{array}{l}-0.0006 \\
(0.0006)\end{array}$ & $\begin{array}{l}-0.0009 \\
(0.0006)\end{array}$ \\
\hline Age & $\begin{array}{c}0.0107 \\
(0.0105)\end{array}$ & $\begin{array}{c}0.0066 \\
(0.0104)\end{array}$ & $\begin{array}{c}0.0040 \\
(0.0121)\end{array}$ \\
\hline Education & $\begin{array}{c}0.0130 \\
(0.0238)\end{array}$ & $\begin{array}{c}0.0215 \\
(0.0236)\end{array}$ & $\begin{array}{c}0.0136 \\
(0.0240)\end{array}$ \\
\hline Nonwhite & $\begin{array}{l}-0.1369 \\
(0.1512)\end{array}$ & $\begin{array}{l}-0.1436 \\
(0.1513)\end{array}$ & $\begin{array}{l}-0.1276 \\
(0.1508)\end{array}$ \\
\hline Poor Health & $\begin{array}{c}0.3859 \\
(0.7693)\end{array}$ & $\begin{array}{c}0.6539 \\
(0.7201)\end{array}$ & $\begin{array}{c}0.3784 \\
(0.7701)\end{array}$ \\
\hline Female & $\begin{array}{c}0.2196 \\
(0.1152)\end{array}$ & $\begin{array}{c}0.2255 \\
(0.1152)\end{array}$ & $\begin{array}{c}0.2247 \\
(0.1174)\end{array}$ \\
\hline Married & $\begin{array}{l}-0.1708 \\
(0.1477)\end{array}$ & $\begin{array}{l}-0.1708 \\
(0.1466)\end{array}$ & $\begin{array}{l}-0.1837 \\
(0.1467)\end{array}$ \\
\hline Tenure & $\begin{array}{c}0.0162 \\
(0.0050)\end{array}$ & $\begin{array}{c}0.0164 \\
(0.0050)\end{array}$ & $\begin{array}{c}0.0148 \\
(0.0050)\end{array}$ \\
\hline Never Married & $\begin{array}{l}-0.5490 \\
(0.3353)\end{array}$ & $\begin{array}{l}-0.4179 \\
(0.3110)\end{array}$ & $\begin{array}{l}-0.5340 \\
(0.3329)\end{array}$ \\
\hline Central City of SMSA & $\begin{array}{l}-0.2508 \\
(0.1175)\end{array}$ & $\begin{array}{l}-0.2731 \\
(0.1170)\end{array}$ & $\begin{array}{l}-0.2534 \\
(0.1168)\end{array}$ \\
\hline $\begin{array}{l}\text { Last Month of } 1983 \\
\text { sample Interviews }\end{array}$ & $\begin{array}{l}-0.3860 \\
(0.2072)\end{array}$ & $\begin{array}{l}-0.4266 \\
(0.2117)\end{array}$ & $\begin{array}{l}-0.4206 \\
(0.2042)\end{array}$ \\
\hline Suspicious, ex-ante & $\begin{array}{l}-0.0796 \\
(0.0450)\end{array}$ & $\begin{array}{l}-0.0796 \\
(0.0451)\end{array}$ & $\begin{array}{l}-0.0797 \\
(0.0452)\end{array}$ \\
\hline Suspicious, ex-post & $\begin{array}{l}-0.2205 \\
(0.0522)\end{array}$ & $\begin{array}{l}-0.2260 \\
(0.0520)\end{array}$ & $\begin{array}{l}-0.2224 \\
(0.0521)\end{array}$ \\
\hline Showed Interest & $\begin{array}{c}0.0218 \\
(0.0628)\end{array}$ & $\begin{array}{c}0.0070 \\
(0.0625)\end{array}$ & $\begin{array}{c}0.0247 \\
(0.0634)\end{array}$ \\
\hline Used Documents & $\begin{array}{l}-0.0526 \\
(0.0482)\end{array}$ & $\begin{array}{l}-0.0694 \\
(0.0474)\end{array}$ & $\begin{array}{l}-0.0530 \\
(0.0457)\end{array}$ \\
\hline \multirow[t]{2}{*}{ Owns Home } & $\begin{array}{c}0.3447 \\
(0.1484)\end{array}$ & $\begin{array}{c}0.3734 \\
(0.1475)\end{array}$ & $\begin{array}{c}0.3486 \\
(0.1489)\end{array}$ \\
\hline & $\begin{array}{c}0.0776 \\
(0.6938)\end{array}$ & $\begin{array}{l}-0.5961 \\
(0.2622)\end{array}$ & $\begin{array}{c}0.0925 \\
(0.6915)\end{array}$ \\
\hline Log-Likelihood & 705.057 & 703.523 & 710.418 \\
\hline \multicolumn{4}{|c|}{$\begin{array}{l}\text { Notes: } \\
\text { a) Dependent variables are } 1 \text { for retirement, } 0 \text { otherwise; } 1 \text { for reinterview, } 0 \text { for attrition } \\
\text { b) Number of Employees: } 520 \text { (688) Number of Observations: } 1389 \text { (1557) } \\
\text { c) Retirement probits include indicator variables for year (2). } \\
\text { d) Re-interview probits include indicator variables for occupation (11). }\end{array}$} \\
\hline
\end{tabular}




\section{Appendix B: Alternative Specifications}

This Appendix includes the alternative specifications of the retirement models referenced in the text. The tables are:

B1: Table 3 with age dummies rather than a linear age term

B2: Table 3 with only male workers included

B3: Table 3 with the high-income sample excluded

B4: Table 3 estimated using sample weights

B5: Tables $3-5$, middle columns, with Social Security and pension variables entered separately 
Table B1

\begin{tabular}{|c|c|c|c|}
\hline Variable & Option Value & $\begin{array}{l}\text { Retirement Wealth } \\
\text { Includes Pension }\end{array}$ & $\begin{array}{l}\text { Retirement Wealth } \\
\text { Excludes Pension }\end{array}$ \\
\hline $\begin{array}{l}\text { Option Value of } \\
\text { Retirement }\end{array}$ & $\begin{array}{l}-0.1707 \\
(0.0705)\end{array}$ & ----- & ----- \\
\hline Retirement Wealth & $\begin{array}{c}0.0008 \\
(0.0006)\end{array}$ & $\begin{array}{c}0.0002 \\
(0.0008)\end{array}$ & $\begin{array}{l}-0.0019 \\
(0.0031)\end{array}$ \\
\hline $\begin{array}{l}\text { Retirement Wealth } \\
\text { Accrual }\end{array}$ & ----- & $\begin{array}{l}-0.0220 \\
(0.0069)\end{array}$ & $\begin{array}{l}-0.0296 \\
(0.0389)\end{array}$ \\
\hline Pension Coverage & ----- & ----- & $\begin{array}{l}-0.1071 \\
(0.0989)\end{array}$ \\
\hline Wage & $\begin{array}{c}0.0043 \\
(0.0030)\end{array}$ & $\begin{array}{l}-0.0021 \\
(0.0013)\end{array}$ & $\begin{array}{l}-0.0009 \\
(0.0009)\end{array}$ \\
\hline Age $=62$ & $\begin{array}{c}0.7292 \\
(0.3166)\end{array}$ & $\begin{array}{c}0.8362 \\
(0.3142)\end{array}$ & $\begin{array}{c}0.8850 \\
(0.3229)\end{array}$ \\
\hline Age $=65$ & $\begin{array}{c}0.7141 \\
(0.3523)\end{array}$ & $\begin{array}{c}0.7651 \\
(0.3463)\end{array}$ & $\begin{array}{c}0.9516 \\
(0.3706)\end{array}$ \\
\hline Education & $\begin{array}{l}-0.0002 \\
(0.0163)\end{array}$ & $\begin{array}{l}-0.0100 \\
(0.0157)\end{array}$ & $\begin{array}{l}-0.0118 \\
(0.0159)\end{array}$ \\
\hline Nonwhite & $\begin{array}{l}-0.1252 \\
(0.1616)\end{array}$ & $\begin{array}{l}-0.1284 \\
(0.1620)\end{array}$ & $\begin{array}{l}-0.1432 \\
(0.1628)\end{array}$ \\
\hline Poor Health & $\begin{array}{c}0.2891 \\
(0.2968)\end{array}$ & $\begin{array}{c}0.3031 \\
(0.2970)\end{array}$ & $\begin{array}{c}0.2983 \\
(0.3006)\end{array}$ \\
\hline Female & $\begin{array}{l}-0.0029 \\
(0.1071)\end{array}$ & $\begin{array}{c}0.0423 \\
(0.1054)\end{array}$ & $\begin{array}{c}0.0435 \\
(0.1069)\end{array}$ \\
\hline Married & $\begin{array}{l}-0.0896 \\
(0.1264)\end{array}$ & $\begin{array}{l}-0.0576 \\
(0.1260)\end{array}$ & $\begin{array}{l}-0.0890 \\
(0.1231)\end{array}$ \\
\hline Tenure & $\begin{array}{l}-0.0079 \\
(0.0047)\end{array}$ & $\begin{array}{l}-0.0090 \\
(0.0048)\end{array}$ & $\begin{array}{l}-0.0035 \\
(0.0046)\end{array}$ \\
\hline Financial Assets & $\begin{array}{l}0.000003 \\
(0.00003)\end{array}$ & $\begin{array}{c}0.00001 \\
(0.00003)\end{array}$ & $\begin{array}{c}0.00002 \\
(0.00003)\end{array}$ \\
\hline Housing Net Equity & $\begin{array}{l}-0.0015 \\
(0.0006)\end{array}$ & $\begin{array}{l}-0.0021 \\
(0.0013)\end{array}$ & $\begin{array}{l}-0.0017 \\
(0.0007)\end{array}$ \\
\hline Log-Likelihood & 439.039 & 440.773 & 450.657 \\
\hline LR Test of Age Dummies & 0.120 & 0.116 & 0.059 \\
\hline \multicolumn{4}{|c|}{$\begin{array}{l}\text { Notes: } \\
\text { a) Dependent variable is } 1 \text { if employee leaves job held in 1983, } 0 \text { otherwise } \\
\text { b) Number of Employees: } 520 \text { Number of Observations: } 1389 \\
\text { c) All dollar amounts are in thousands. } \\
\text { d) All specifications include indicator variables for year (2). } \\
\text { e) Standard errors are adjusted for heteroskedasticity and clustering within households. }\end{array}$} \\
\hline
\end{tabular}


Table B2

\begin{tabular}{|c|c|c|c|}
\hline \multicolumn{4}{|c|}{ Retirement Probits -- Dependent Variable Includes All Job Changes--Males Only } \\
\hline Variable & Option Value & $\begin{array}{l}\text { Retirement Wealth } \\
\text { Includes Pension }\end{array}$ & $\begin{array}{l}\text { Retirement Wealth } \\
\text { Excludes Pension }\end{array}$ \\
\hline $\begin{array}{l}\text { Option Value of } \\
\text { Retirement }\end{array}$ & $\begin{array}{l}-0.1607 \\
(0.0527)\end{array}$ & ----- & ----- \\
\hline Retirement Wealth & $\begin{array}{c}0.0012 \\
(0.0005)\end{array}$ & $\begin{array}{c}0.0008 \\
(0.0007)\end{array}$ & $\begin{array}{l}-0.00005 \\
(0.0363)\end{array}$ \\
\hline $\begin{array}{l}\text { Retirement Wealth } \\
\text { Accrual }\end{array}$ & ----- & $\begin{array}{l}-0.0150 \\
(0.0060)\end{array}$ & $\begin{array}{l}-0.0077 \\
(0.0244)\end{array}$ \\
\hline Pension Coverage & ----- & ----- & $\begin{array}{c}0.1425 \\
(0.1340)\end{array}$ \\
\hline Wage & $\begin{array}{c}0.0037 \\
(0.0020)\end{array}$ & $\begin{array}{l}-0.0019 \\
(0.0013)\end{array}$ & $\begin{array}{l}-0.0006 \\
(0.0008)\end{array}$ \\
\hline Age & $\begin{array}{c}0.0148 \\
(0.0147)\end{array}$ & $\begin{array}{c}0.0243 \\
(0.0137)\end{array}$ & $\begin{array}{c}0.0405 \\
(0.0165)\end{array}$ \\
\hline Education & $\begin{array}{l}-0.0100 \\
(0.0199)\end{array}$ & $\begin{array}{l}-0.0253 \\
(0.0197)\end{array}$ & $\begin{array}{l}-0.0343 \\
(0.0192)\end{array}$ \\
\hline Nonwhite & $\begin{array}{l}-0.3180 \\
(0.2557)\end{array}$ & $\begin{array}{l}-0.3341 \\
(0.2560)\end{array}$ & $\begin{array}{l}-0.3641 \\
(0.2617)\end{array}$ \\
\hline Poor Health & $\begin{array}{c}0.3141 \\
(0.3439)\end{array}$ & $\begin{array}{c}0.3106 \\
(0.3498)\end{array}$ & $\begin{array}{c}0.3768 \\
(0.3674)\end{array}$ \\
\hline Female & ----- & ----- & ----- \\
\hline Married & $\begin{array}{l}-0.0598 \\
(0.2297)\end{array}$ & $\begin{array}{c}0.0007 \\
(0.2279)\end{array}$ & $\begin{array}{c}0.0175 \\
(0.2127)\end{array}$ \\
\hline Tenure & $\begin{array}{l}-0.0129 \\
(0.0057)\end{array}$ & $\begin{array}{l}-0.0126 \\
(0.0058)\end{array}$ & $\begin{array}{l}-0.0102 \\
(0.0056)\end{array}$ \\
\hline Financial Assets & $\begin{array}{c}0.00001 \\
(0.00003)\end{array}$ & $\begin{array}{c}0.00002 \\
(0.00003)\end{array}$ & $\begin{array}{c}0.00004 \\
(0.00003)\end{array}$ \\
\hline Housing Net Equity & $\begin{array}{l}-0.0013 \\
(0.0006)\end{array}$ & $\begin{array}{l}-0.0017 \\
(0.0007)\end{array}$ & $\begin{array}{l}-0.0014 \\
(0.0007)\end{array}$ \\
\hline Constant & $\begin{array}{l}-1.2885 \\
(0.8955)\end{array}$ & $\begin{array}{l}-1.9005 \\
(0.8301)\end{array}$ & $\begin{array}{l}-2.8588 \\
(0.9523)\end{array}$ \\
\hline Log-Likelihood & 252.717 & 255.644 & 263.262 \\
\hline \multicolumn{4}{|c|}{$\begin{array}{l}\text { Notes: } \\
\text { a) Dependent variable is } 1 \text { if employee leaves job held in } 1983,0 \text { otherwise } \\
\text { b) Number of Employees: } 312 \text { Number of Observations: } 836 \\
\text { c) All dollar amounts are in thousands. } \\
\text { d) All specifications include indicator variables for year (2). }\end{array}$} \\
\hline
\end{tabular}


Table B3

\begin{tabular}{|c|c|c|c|}
\hline \multicolumn{4}{|c|}{ Retirement Probits -- Dependent Variable Includes All Job Changes, High-Income Sample Excluded } \\
\hline Variable & Option Value & $\begin{array}{l}\text { Retirement Wealth } \\
\text { Includes Pension }\end{array}$ & $\begin{array}{l}\text { Retirement Wealth } \\
\text { Excludes Pension }\end{array}$ \\
\hline $\begin{array}{l}\text { Option Value of } \\
\text { Retirement }\end{array}$ & $\begin{array}{l}-0.2090 \\
(0.1029)\end{array}$ & ----- & ----- \\
\hline Retirement Wealth & $\begin{array}{l}-0.0002 \\
(0.0011)\end{array}$ & $\begin{array}{l}-0.0018 \\
(0.0013)\end{array}$ & $\begin{array}{c}0.0003 \\
(0.0032)\end{array}$ \\
\hline $\begin{array}{l}\text { Retirement Wealth } \\
\text { Accrual }\end{array}$ & ----- & $\begin{array}{l}-0.0449 \\
(0.0120)\end{array}$ & $\begin{array}{l}-0.0265 \\
(0.0285)\end{array}$ \\
\hline Pension Coverage & ----- & ----- & $\begin{array}{l}-0.2774 \\
(0.1105)\end{array}$ \\
\hline Wage & $\begin{array}{c}0.0046 \\
(0.0064)\end{array}$ & $\begin{array}{l}-0.0067 \\
(0.0038)\end{array}$ & $\begin{array}{l}-0.0062 \\
(0.0034)\end{array}$ \\
\hline Age & $\begin{array}{c}0.0281 \\
(0.0131)\end{array}$ & $\begin{array}{c}0.0311 \\
(0.0125)\end{array}$ & $\begin{array}{c}0.0394 \\
(0.0132)\end{array}$ \\
\hline Education & $\begin{array}{c}0.0052 \\
(0.0179)\end{array}$ & $\begin{array}{c}0.0030 \\
(0.0175)\end{array}$ & $\begin{array}{c}0.0019 \\
(0.0169)\end{array}$ \\
\hline Nonwhite & $\begin{array}{l}-0.1351 \\
(0.1666)\end{array}$ & $\begin{array}{l}-0.1310 \\
(0.1678)\end{array}$ & $\begin{array}{l}-0.1431 \\
(0.1682)\end{array}$ \\
\hline Poor Health & $\begin{array}{c}0.2612 \\
(0.2859)\end{array}$ & $\begin{array}{c}0.2752 \\
(0.2853)\end{array}$ & $\begin{array}{c}0.2091 \\
(0.2971)\end{array}$ \\
\hline Female & $\begin{array}{l}-0.0125 \\
(0.1158)\end{array}$ & $\begin{array}{c}0.0070 \\
(0.1187)\end{array}$ & $\begin{array}{c}0.0077 \\
(0.1161)\end{array}$ \\
\hline Married & $\begin{array}{l}-0.1007 \\
(0.1284)\end{array}$ & $\begin{array}{l}-0.0893 \\
(0.1285)\end{array}$ & $\begin{array}{l}-0.1008 \\
(0.1279)\end{array}$ \\
\hline Tenure & $\begin{array}{l}-0.0022 \\
(0.0060)\end{array}$ & $\begin{array}{l}-0.0031 \\
(0.0061)\end{array}$ & $\begin{array}{c}0.0026 \\
(0.0052)\end{array}$ \\
\hline Financial Assets & $\begin{array}{c}0.0004 \\
(0.0006)\end{array}$ & $\begin{array}{c}0.0005 \\
(0.0006)\end{array}$ & $\begin{array}{c}0.0004 \\
(0.0006)\end{array}$ \\
\hline Housing Net Equity & $\begin{array}{l}-0.0015 \\
(0.0013)\end{array}$ & $\begin{array}{l}-0.0018 \\
(0.0013)\end{array}$ & $\begin{array}{l}-0.0018 \\
(0.0013)\end{array}$ \\
\hline Constant & $\begin{array}{l}-2.2274 \\
(0.8413)\end{array}$ & $\begin{array}{l}-2.4765 \\
(0.7678)\end{array}$ & $\begin{array}{l}-2.9745 \\
(0.7796)\end{array}$ \\
\hline Log-Likelihood & 382.110 & 381.066 & 386.594 \\
\hline \multicolumn{4}{|c|}{$\begin{array}{l}\text { Notes: } \\
\text { a) Dependent variable is } 1 \text { if employee leaves job held in 1983,0 otherwise } \\
\text { b) Number of Employees: } 403 \text { Number of Observations: } 1061 \\
\text { c) All dollar amounts are in thousands. } \\
\text { d) All specifications include indicator variables for year (2). }\end{array}$} \\
\hline
\end{tabular}


Table B4

\begin{tabular}{|c|c|c|c|}
\hline \multicolumn{4}{|c|}{ Retirement Probits -- Dependent Variable Includes All Job Changes, Sample Weights Utilized } \\
\hline Variable & Option Value & $\begin{array}{l}\text { Retirement Wealth } \\
\text { Includes Pension }\end{array}$ & $\begin{array}{l}\text { Retirement Wealth } \\
\text { Excludes Pension }\end{array}$ \\
\hline $\begin{array}{l}\text { Option Value of } \\
\text { Retirement }\end{array}$ & $\begin{array}{l}-0.2438 \\
(0.0633)\end{array}$ & ----- & ----- \\
\hline Retirement Wealth & $\begin{array}{l}-0.0003 \\
(0.0009)\end{array}$ & $\begin{array}{l}-0.0012 \\
(0.0012)\end{array}$ & $\begin{array}{c}0.0013 \\
(0.0031)\end{array}$ \\
\hline $\begin{array}{l}\text { Retirement Wealth } \\
\text { Accrual }\end{array}$ & ----- & $\begin{array}{l}-0.0337 \\
(0.0101)\end{array}$ & $\begin{array}{l}-0.0199 \\
(0.0272)\end{array}$ \\
\hline Pension Coverage & ----- & ----- & $\begin{array}{l}-0.2406 \\
(0.1105)\end{array}$ \\
\hline Wage & $\begin{array}{c}0.0082 \\
(0.0029)\end{array}$ & $\begin{array}{l}-0.0031 \\
(0.0026)\end{array}$ & $\begin{array}{l}-0.0031 \\
(0.0023)\end{array}$ \\
\hline Age & $\begin{array}{c}0.0274 \\
(0.0128)\end{array}$ & $\begin{array}{c}0.0361 \\
(0.0125)\end{array}$ & $\begin{array}{c}0.0411 \\
(0.0133)\end{array}$ \\
\hline Education & $\begin{array}{c}0.0096 \\
(0.0175)\end{array}$ & $\begin{array}{c}0.0017 \\
(0.0172)\end{array}$ & $\begin{array}{l}-0.0005 \\
(0.0168)\end{array}$ \\
\hline Nonwhite & $\begin{array}{c}-0.1630 \\
(0.1680)\end{array}$ & $\begin{array}{l}-0.1603 \\
(0.1675)\end{array}$ & $\begin{array}{l}-0.1634 \\
(0.1672)\end{array}$ \\
\hline Poor Health & $\begin{array}{c}0.1815 \\
(0.3100)\end{array}$ & $\begin{array}{c}0.2041 \\
(0.3099)\end{array}$ & $\begin{array}{c}0.1489 \\
(0.3201)\end{array}$ \\
\hline Female & $\begin{array}{l}-0.0407 \\
(0.1164)\end{array}$ & $\begin{array}{l}-0.0048 \\
(0.1171)\end{array}$ & $\begin{array}{c}0.0050 \\
(0.1170)\end{array}$ \\
\hline Married & $\begin{array}{l}-0.1730 \\
(0.1310)\end{array}$ & $\begin{array}{l}-0.1378 \\
(0.1301)\end{array}$ & $\begin{array}{l}-0.1550 \\
(0.1302)\end{array}$ \\
\hline Tenure & $\begin{array}{l}-0.0042 \\
(0.0058)\end{array}$ & $\begin{array}{l}-0.0054 \\
(0.0059)\end{array}$ & $\begin{array}{c}0.0002 \\
(0.0052)\end{array}$ \\
\hline Financial Assets & $\begin{array}{l}-0.00004 \\
(0.00008)\end{array}$ & $\begin{array}{l}-0.00006 \\
(0.00010)\end{array}$ & $\begin{array}{c}0.00000 \\
(0.00007)\end{array}$ \\
\hline Housing Net Equity & $\begin{array}{l}-0.0015 \\
(0.0009)\end{array}$ & $\begin{array}{l}-0.0017 \\
(0.0009)\end{array}$ & $\begin{array}{l}-0.0017 \\
(0.0010)\end{array}$ \\
\hline Constant & $\begin{array}{l}-2.1352 \\
(0.8009)\end{array}$ & $\begin{array}{l}-2.7539 \\
(0.7751)\end{array}$ & $\begin{array}{l}-3.0844 \\
(0.8023)\end{array}$ \\
\hline Log-Likelihood & 497.441 & 501.420 & 507.103 \\
\hline \multicolumn{4}{|c|}{$\begin{array}{l}\text { Notes: } \\
\text { a) Dependent variable is } 1 \text { if employee leaves job held in 1983, } 0 \text { otherwise } \\
\text { b) Number of Employees: } 520 \text { Number of Observations: } 1389 \\
\text { c) All dollar amounts are in thousands. } \\
\text { d) All specifications include indicator variables for year (2). }\end{array}$} \\
\hline
\end{tabular}


Table B5

\begin{tabular}{|c|c|c|c|}
\hline \multicolumn{4}{|c|}{ Retirement Probits -- Pensions and Social Security Variables Entered Separately } \\
\hline Variable & Table 3 & Table 4 & Table 5 \\
\hline Social Security Wealth & $\begin{array}{c}0.0002 \\
(0.0027)\end{array}$ & $\begin{array}{c}-0.0008 \\
(0.0036)\end{array}$ & $\begin{array}{c}-0.0030 \\
(0.0044)\end{array}$ \\
\hline Social Security Accrual & $\begin{array}{l}-0.0161 \\
(0.0225)\end{array}$ & $\begin{array}{l}-0.0360 \\
(0.0279)\end{array}$ & $\begin{array}{l}-0.0405 \\
(0.0331)\end{array}$ \\
\hline Pension Wealth & $\begin{array}{c}0.0002 \\
(0.0008)\end{array}$ & $\begin{array}{c}0.0003 \\
(0.0012)\end{array}$ & $\begin{array}{c}-0.0012 \\
(0.0009)\end{array}$ \\
\hline Pension Accrual & $\begin{array}{c}-0.0222 \\
(0.0074)\end{array}$ & $\begin{array}{l}-0.0208 \\
(0.0089)\end{array}$ & $\begin{array}{l}-0.0198 \\
(0.0077)\end{array}$ \\
\hline Wage & $\begin{array}{l}-0.0019 \\
(0.0013)\end{array}$ & $\begin{array}{l}-0.0056 \\
(0.0018)\end{array}$ & $\begin{array}{c}-0.0002 \\
(0.0012)\end{array}$ \\
\hline Age & $\begin{array}{c}0.0312 \\
(0.0121)\end{array}$ & $\begin{array}{c}0.0776 \\
(0.0169)\end{array}$ & $\begin{array}{c}0.0676 \\
(0.0178)\end{array}$ \\
\hline Education & $\begin{array}{l}-0.0121 \\
(0.0154)\end{array}$ & $\begin{array}{l}-0.0069 \\
(0.0207)\end{array}$ & $\begin{array}{c}0.0026 \\
(0.0225)\end{array}$ \\
\hline Nonwhite & $\begin{array}{c}-0.1303 \\
(0.1607)\end{array}$ & $\begin{array}{c}-0.0568 \\
(0.1901)\end{array}$ & $\begin{array}{l}-0.3228 \\
(0.2195)\end{array}$ \\
\hline Poor Health & $\begin{array}{c}0.2892 \\
(0.2892)\end{array}$ & $\begin{array}{c}0.2508 \\
(0.5530)\end{array}$ & $\begin{array}{c}0.6783 \\
(0.1743)\end{array}$ \\
\hline Female & $\begin{array}{c}0.0466 \\
(0.1094)\end{array}$ & $\begin{array}{c}0.2356 \\
(0.1462)\end{array}$ & $\begin{array}{c}-0.0082 \\
(0.1543)\end{array}$ \\
\hline Married & $\begin{array}{c}-0.0598 \\
(0.1256)\end{array}$ & $\begin{array}{l}-0.0656 \\
(0.1606)\end{array}$ & $\begin{array}{l}-0.2110 \\
(0.1606)\end{array}$ \\
\hline Tenure & $\begin{array}{c}-0.0088 \\
(0.0048)\end{array}$ & $\begin{array}{c}0.0054 \\
(0.0062)\end{array}$ & $\begin{array}{c}0.0109 \\
(0.0065)\end{array}$ \\
\hline Financial Assets & $\begin{array}{c}0.00002 \\
(0.00003)\end{array}$ & $\begin{array}{c}0.00002 \\
(0.00004)\end{array}$ & $\begin{array}{c}0.00003 \\
(0.00004)\end{array}$ \\
\hline Housing Net Equity & $\begin{array}{c}-0.0019 \\
(0.0007)\end{array}$ & $\begin{array}{c}-0.0016 \\
(0.0008)\end{array}$ & $\begin{array}{c}-0.0020 \\
(0.0009)\end{array}$ \\
\hline Constant & $\begin{array}{c}-2.4191 \\
(0.7238)\end{array}$ & $\begin{array}{l}-5.9058 \\
(0.9953)\end{array}$ & $\begin{array}{c}-4.7778 \\
(1.0674)\end{array}$ \\
\hline Log-Likelihood & 453.988 & 233.901 & 246.333 \\
\hline Tests of equality p-values: & & & \\
\hline Retirement wealths & 0.9801 & 0.7673 & 0.6899 \\
\hline Retirement accruals & 0.8018 & 0.6132 & 0.5658 \\
\hline \multicolumn{4}{|c|}{$\begin{array}{l}\text { Notes: } \\
\text { a) Dependent variables and number of observations are the same as in the specified table. } \\
\text { b) All dollar amounts are in thousands. } \\
\text { c) All specifications include indicator variables for year (2). }\end{array}$} \\
\hline
\end{tabular}

